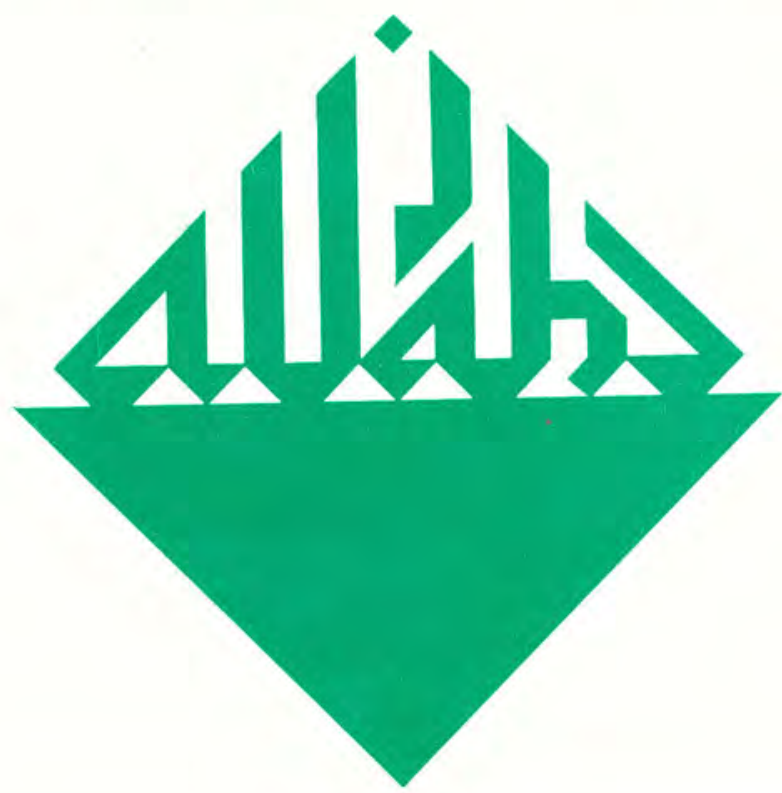

PESANTREN AND TAREKAT IN THE MODERN ERA:

AN ACCOUNT ON THE TRANSMISSION OF TRADITIONAL ISLAM IN JAVA

A. G. Muhaimin

INDONESIA'S NURCHOLISH MADJID AND ABDURRAHMAN WAHID AS !NTELLECTUAL ULAMÂ! THE MEETING OF ISLAMIC TRADITIONALISM AND MODERNISM IN NEO-MODERNIST THOUGHT

\title{
Greg Barton
}

INDONESIA'S EMERGING MUSLIM FEMINISM: WOMEN LEADERS ON EQUALITY, INHERITANCE AND OTHER GENDER ISSUES

\section{Andrée Feillard}

SUFISM, POWER POLITICS, AND REFORM: AL-RÂNÎRÎ'S OPPOSITION TO HAMZAH AL-FANSÛRî'S TEACHINGS RECONSIDERED

Abdollah Vakily 


\section{STIIDIA ISLAMIIKI}

Indonesian Journal for Islamic Studies

Volume 4, Number 1, 1997

\section{EDITORIAL BOARD;}

Harun Nasution

Mastubu

M. Quraish Shibab

A. Aziz Dahlan

M. Satria Effendi

Nabilab Lubis

M. Yunan Yusuf

Komaruddin Hidayat

M. Din Syamsuddin

Muslim Nasution

Wabib Mu'tbi

EDITOR-IN-CHIEF:

Azyumardi Azra

EDITORS:

Saiful Mujani

Hendro Prasetyo

Joban H. Meuleman

Didin Syafruddin

Ali Munbanif

ASSISTANTS TO THE EDITOR:

Arief Subban

Oman Fatburrabman

Heni Nuroni

ENGLISH LANGUAGE ADVISOR:

Kay Bridger

ARABIC LANGUAGE ADVISOR:

Fuad M. Facbruddin

COVER DESIGNER:

S. Prinka

STUDLA ISLAMIKA (ISSN 0215-0492) is a journal published quarterly by the Institut Agama Islam Negeri (IAIN. The State Institute for Islamic Studies) Syarif Hidayatullah, Jakarta. (STT DEPPEN No. 129/SK/DITJEN/PPG/STT/1976) and sponsored by the Department of Religious Affatrs of the Republic of Indonesia. It specializes in Indonesian Istamic studies, and is intended to communicate original researches and current issues on the subject. This journal warmly welcomes contributions from scholars of related disciplines.

All articles published do not necessarily represent the views of the journal, or other institutions to which it is affiliated. They are solely the views of the authors. 


\title{
Tațawwur al-Tarbiyah al-Islâmiyyah (Surau) fî Minangkabau
}

\begin{abstract}
The spread of Islam in Minangkabau, West Sumatera, cannot be separated from the development of Islamic learning centers that existed in Malay traditional colleges (popularly called surau). Within the context of Islamizing Java, the role of these colleges shared a similar position to that of pesantren, traditional boarding schools which for a long time became the centers of Islamization on the island. Since their foundation, surau have served a center for the creation of Muslim scholars who were responsible for the transmission of Islamic doctrines and knowledge and who tried to build a community which was committed to these doctrines. The surau developed over time in a variety of ways.

In the beginning, the suraus were not an educational institution. They already existed long before the coming of Islam to the region. In brief, it can be concluded that the suraus were genuinely originated from Minangkaban culture and served as a place for meeting, gathering, consulting and baving a rest for young and old male Minangkabaus, especially divorcees. The suraus also served as a place to stay over night for travelers and traders when they were passing through a village. The suraus, then, became an information center and a place for socialization among the peoples of Minangkabau tradition.
\end{abstract}

When Islam came to Minangkabau, the 'ulama' who became leading figures in the preaching of Islam transformed this institution into an Islamic education institution. They did not change the traditional function of the suraus in a radical way, but add new functions so that the suraus would serve as a center for the propagation and study of Islam following along the line of what had existed in mosques in Islamic bistory. The suraus developed not only as a place of stay or for other pleastire activities, but also served as a place in which to perform daily prayers, to study religious subjects, and to bold other Islamic ceremonies.

In terms of its role as a learning institution, educational activities in the surau can be divided into two levels: an elementary level for $Q$ ur'anic recitation and a higher level for religious studies. The system ran as follows: having 
finished the study of the Qur'anic recitation, some students continued their studies at a bigher level of learning of religious studies. The subjects provided at this level consisted of Arabic grammar and tenses, since this knowledge was considered as a main tool in understanding other Islamic sciences. The method used in this study usually took the form of memorizing grammatical categories and tenses in Arabic language, but at the same time translating them into Minangkabau. The students of the suraus studied classical Islamic books such as Kitâb Dhammun (Book on Grammar), al-'Awâmil al-Mi'ah , al-Jurûmiyyah and Syarh al-'Awâmil al-Mi'ah.

After completing their studies in Arabic grammar, the students usually continued their studies in the subject of Islamic jurisprudence. Several sub. jects that can be mentioned at this level were religious worship, charity, fasting, the pilgrimage to Mecca, and subjects on Islamic trade. The suraus generally used Kitâb Minhaj al-Tâlibîn (The Students' Guide Book) as a recommended book for Islamic jurisprudence. The book was written in a beautiful Arabic prose, but it was very simple and easily understood. Having finished reading the book, the students went on to study methodology of Qur'ânic exigesis by reciting a book written in medieval Islam, Tafsîr al-Jalâlayn (Exegesis of T wo Greatness). In addition to studying those subjects, some students who had license to do so also deepened their knowledge by studying Islamic theology, logics and Islamic mysticism.

One of the leading suraus in Minangkabau was Surau Burhanuddin (Burbân al-Dîn) established in Ulakan Pariaman in the seventeenth century which later became a center for propagating Islam. Burbân al-Din (1646. 1692) was the student of Abdurranf Singkel ('Abd al-Ra' $\hat{\text { iff }}$ al-Sinkilit -1615. 1693). He learnt under al-Sinkilî in Aceh for several years and returned to Ulakan in 1680 and established bis own surau. It is said that almost all ulamâs in Minangkabau studied under his supervision. Burbân al-Dîn's popularity is found in the fact that to this day many people come to visit his grave, especially during Safar (the second month of Islamic calender). The Minangkabau call this festival Basafa' or visit in the month of Safar.

The success of his Surau's educational activities is marked by the number of his successors and followers. It goes without saying that Burbân al-Din's students, after finishing their studies, returned to their town and founded suraus in accordance with their expertise. Among Burbân al-Din's students were Taunku Nan Tuo of Paninjauan, Tuanku Nan Tuo of Mansiangan, Tuanku Nan Tuo of Kamang and, the most well known in Minangkabaw. Tuanku Nan Tuo (1723-1830) of Cangking Koto Tuo IV Angkat Agam. All of them became respected religious teachers for thousands of students from surrounding villages in West Sumatera. 


\section{Tațawwur al-Tarbiyah al-Islâmiyyah (Surau) fî Minangkabau}

Abstraksi: Perkembangan Islam di Minangkabau tak dapat dipisahkan dari perkembangan pendidikan dan penyiaran Islam yang berlangsung di surausurau. Posisi surau di Minangkabau sama pentingnya dengan posisi pesantren dalam konteks perkembangan Islam di Pulau Jawa. Sebagaimana pesantren, surau merupakan agen pencetak para ulama yang bertanggung jawab untuk mentransmisikan ajaran Islam dan membangun masyarakat menjadi umat yang taat atas ajaran-ajarannya.

Surau pada awalnya bukan merupakan lembaga pendidikan Islam. Surau telah ada jauh sebelum kehadiran Islam. Surau adalah unsur kebudayaan asli suku Minangkabau yang berfungsi sebagai tempat bertemu, berkumpul, berapat dan tempat tidur bagi pemuda-pemuda dan para lelaki. Sebingga surau menjadi pusat informasi dan sosialisasi para pemudd.

Para ulama Minangkabau mentransformasi surau menjadi lembaga pendidikan Islam. Mereka tidak mengadakan perubahan radikal terbadap fungsi surau, melainkan hanya menambahkan fungsi dan makna mesjid seperti yang telah berkembang secara umum dalam sejarab Islam. Surau dikembangkan juga berfungsi sebagai tempat salat lima waktu, tempat mengaji dan belajar agama, tempat upacara agama dan lain-lain.

Salab satu surau terpenting di Minangkabau ialah Surau Syaikh Burbanuddin di Ulakan Pariaman yang telah ada sejak akbir abad 17 dan merupakan pusat pengembangan Islam. Burhanuddin (1646- 
1692) adalah di antara murid Abdurrauf Singkel(1615-1693). Ia belajar kepada Abdurrauf Singkel di Aceh beberapa tahun. Kemudian ia kembali ke Ulakan Pariaman tahun 1680 dan mendidirikan suran di Ulakan. Hampir semua ulama Minangkabau generasi berikutnya berguru kepadanya. Kemasyhuran Burhanuddin hingga kini masib terlihat dengan banyaknya para penziarah yang mengunjungi ma. kamnya setiap tahun pada bulan Safar yang terkenal dengan istilah 'basafa' (bersafar). Di tempat itu, pengunjung melaksanakan ibadat dengan, misalnya, berdzikir yang diikuti dengan tarian dan nyanyi. an.

Keberhasilan pendidikan Surau Burhanuddin di Ulakan terlibat dari perkembangan dan jumlah muridnya. Mereka yang telah menamatkan pelajaran di surau Burhanuddin, kembali ke kampung masing-masing, dan mendirikan lembaga pendidikan Islam sesuai dengan keahlian yang mereka miliki. Di antara murid Burhanuddin yang termasybur - atau murid dari muridnya dan seterusnyaialab Taunku Nan Tuo di Paninjauan, Tuanku Nan Tuo di Mansiangan, Tuanku Nan Tuo di Kamang dan yang paling termasyhur Tuanku Nan Tuo (1723-1830) di Cangking Koto Tuo IV Angkat Agam. Tuanku Nan Tuo di Cangking Koto Tuo mengamalkan syari'at dan hakikat. Ia belajar kepada Tuanku Nan Tuo di Paninjauan, Mansiangan dan Tuanku Nan Tuo di Kamang. Ketiga Tuanku ini belajar langsung kepada Burhanuddin Ulakan. Setelah belajar ke pelbagai guru, Tuanku Nan Tuo di Cangking Koto Two menjadi syaikh yang alim dalam pelbagai ilmu keislaman.

Para murid Tuanku Nan Tuo di Cangking Koto Tuo seperti Jalaluddin yang termasyhur dengan gelar Fakih Shaghir dan Tuanku Nan Renceh (1772-1832) melakukan bal yang sama sebingga pengikut menjadi penganut yang benar-benar mengamalkan syari'ah. Perkembangan Islam di Minangkabau yang menekankan segi syari'ah di samping hakikat pada dasarnya tak dapat dipisahkan dari pemahaman Islam yang ditransmisikan di surau-surau yang terutama berasal dari Surau Burhanuddin Ulakan Pariaman. Pada saat pemikiran Islam di Haramayn semakin dikuasai para pendukung Wahabi, perkembangan pemikiran Islam surau mencerminkan kecenderung. an yang sama. Surau semakin menekankan pemahaman literal syari ah sehingga lembaga pendidikan Islam ini dipandang sebagai cikal bakal kelahiran Gerakan Kaum Padri di Minangkabau. 


\section{موليانه}

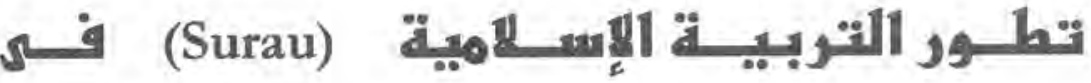 مين+بنكابو}

أ- هصدر ظهور Surau (الزاوية) وتطورها:

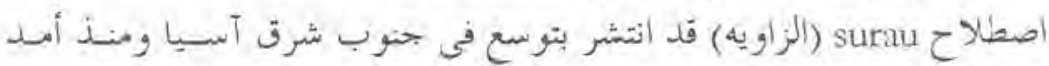
بعيد قد تطور فيى إقليم مينخكابو(Minangkabau)، وباتك(Batak)، وسومطرة الوسطى وسيومطرة الجنوبيسة، وكذلك في شبه جزيرة ماليزيا (Malaysia)

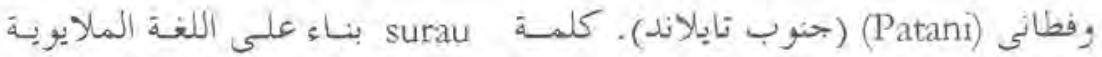
بمعى" "مكان" أو مكان للعبادة أو التقديس.

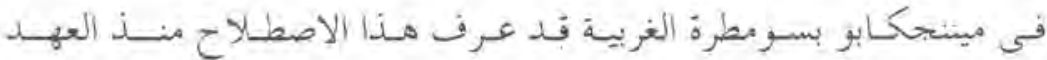

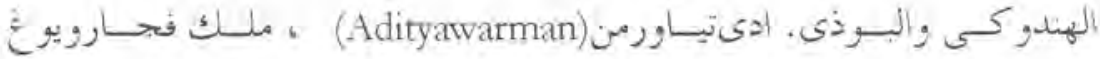
(Pagaruyung)

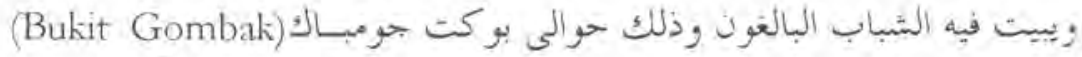

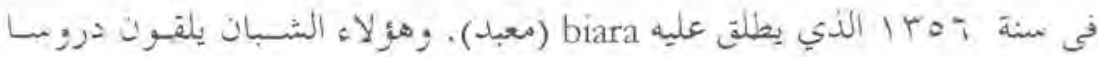
ليتية نافعة لحياتهم الاجتماعية'. 
قال سيدى غُزالبا (Sidi Gazalba) إن هذه الزاوية فى البدايـة تصسور العنصسر الثقافى الأصلى لقبيلة ملايو المتصل بالعقيدة التى تعتقدها بعد دخول الإسـلام إلى هذا الأرخبيل نصارت surau مركزا إسلاميا. كان في القديم surau عبـارة عسن مكان اللقاءات، والاجتماعات وعقد الجلسات ومكان مبيت الشباب، ورالمعبرين

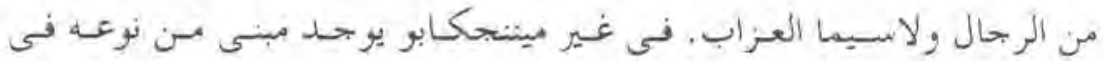

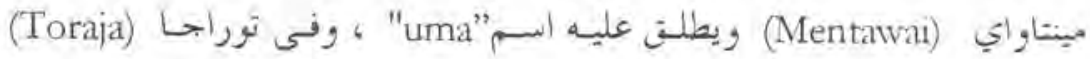
الشرقية يسمونه "lobo" وفى آتشيه يطلقون عليس" "meunasah" ، وفى جـاوة يسمبونه "langgar"

(indu). باء على فهم العادات المينتجكابوية ملـك القوم أو إنـاء surau ,

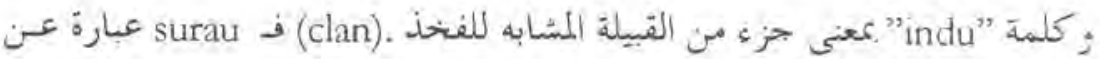
إثمام الدار الكبيرة (rumah gadang) (بيت كبير للعادات) ولكن ليسي كل السدار المبيرة تملك surau (الزاوية)، لأن الزوايا (surau) الموجودة مازالت قـادرة على همع الشبان" ، بما أن الزاوية تقوم بالمهمة التى ذكرئاها فإنها كذلك تكرن مكـات

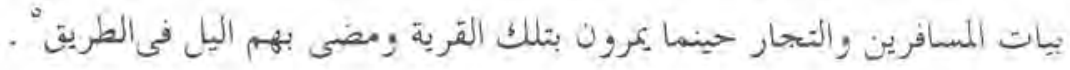

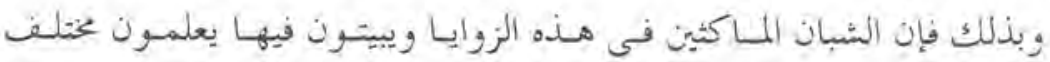

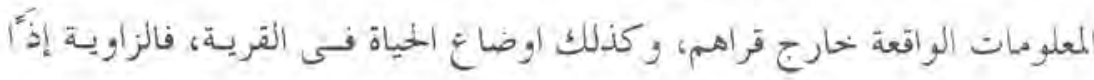

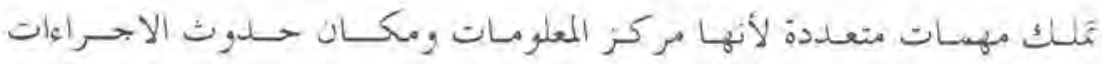
الاجتماعية بين الثشبان. إن التعليم الإسهلامى بدأ يتوسع فى الأرخبيل حوالى النصف الثانى هـن القـرن السابع عشر. العلماء الذين نشروا هذا الدين لم يغيروا الوضع عشوائية خور المبـانى

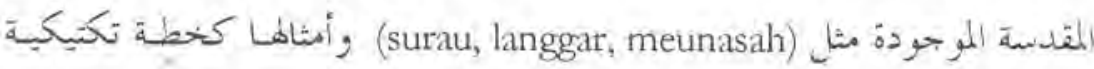

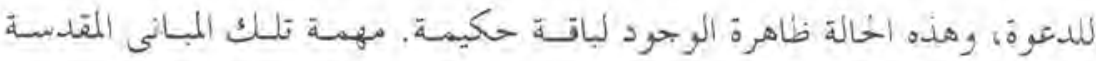
زمعناها زادا شأنا بدخول مهيمة ومعنى المستدل في الإسلاحم، فُسى بعض المناطق 
كثير ا ما يوجل مسجد مبنى بجانب زاوية (surau) أو كلا هما مفصوح بناؤهما

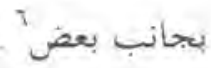
بذلك، أن surau (الزاويـة) أدركت الإجهراعات الجاريسة لإسـلاميتها يعنى بجانب أنها مكان البيات للشبان والأنشطة الأخرى هـى كذلك مكان الصـلاة

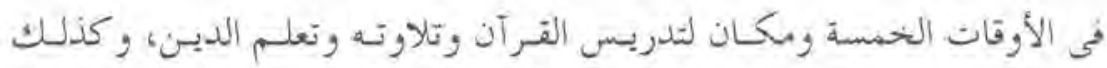
ككان للمبر انسبم الدينية والطريقة الصوفية وغير ذلك. في مينتجكابو، surau (الزاوية) يملكها كل قبيلة (على الأفل توجسد أربعهة

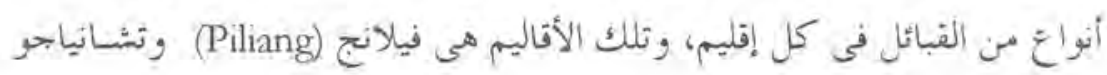
surau (Caniago)

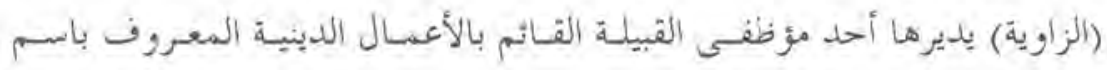

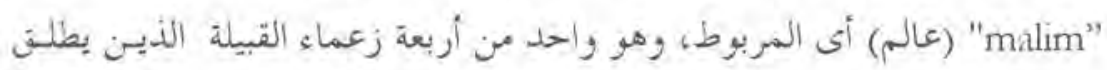

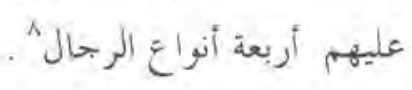

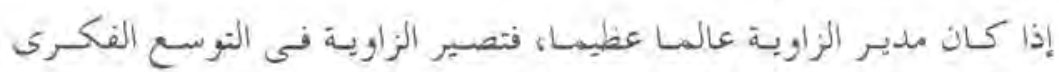
والتطورى فلا تكرن مكان تعليم القرآن فحسب، وركنه مركز للتربية الإسـلامية

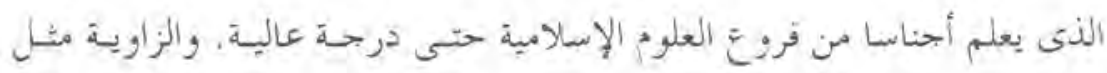

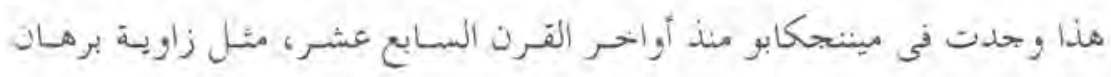

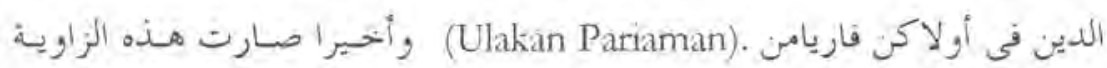
مركز نشر الإسلام و تعليمم التصوف . حسب رأى هحمود يونس أن الزأوية، التى بناها برهـان الديسن في أولاكئ

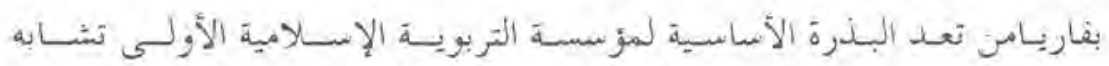
pesantren البر امج و أسلوب التربية الثى نستعمل وكذلك الكتب التى يستفيد منها فى تلـك 


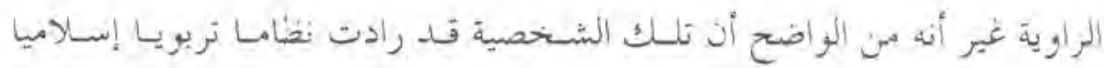

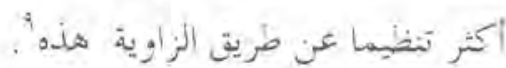
فنجاح زاوية برهان الدين يمكي أن برى هن تطور ثلاميذها وجملة عددهم.

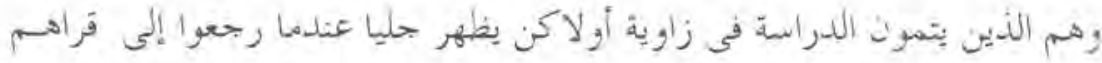
وبنوا فيها زاوية نعرف بانسم زاوية شاطرية كمكان للتدريس نتفقا ونطاء القدرة

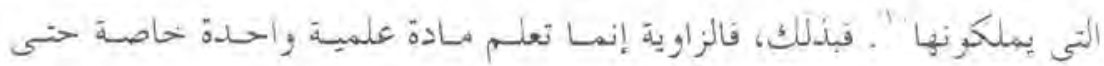
أجب التلاميذذ زيادة مادة علمية أخرى ذهبوا إلى زاوية أحرى للحصبول عليها. إن شهرة برهان الدين ما زألت حية إلى وفتنا الحاضر . هذا الأمر تثبته كمثرة

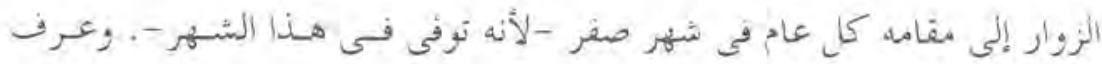

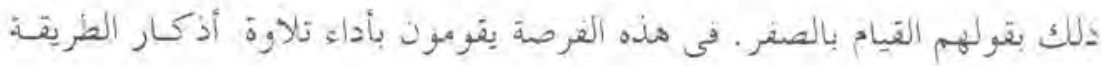

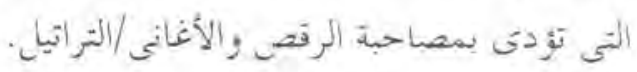

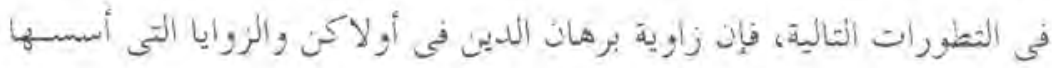

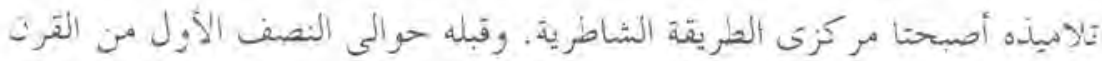
السابع غشر قد رجدت بعض زوايا في أعماق مينحككابر التى صسارت مراكيز ضر يقة النتشانسدية التى برزت في منطقة لِيمافولوه كوتا Lima Puluh Kota)

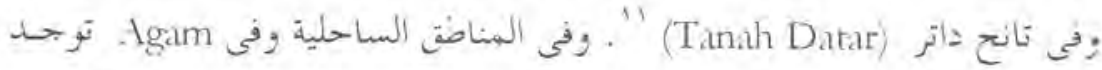

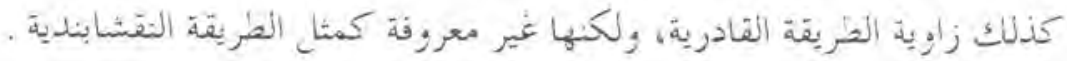

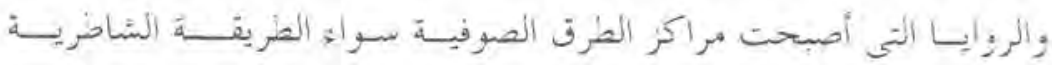

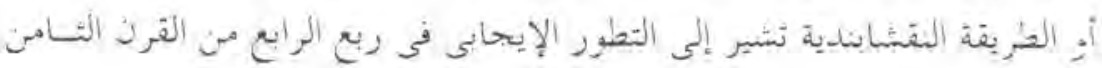
عشبر كما سنبحث في الفصرول الآتية

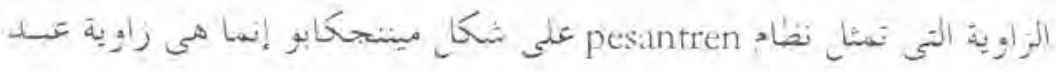

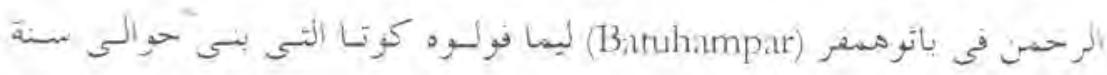

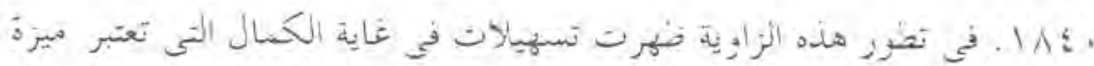


حاصة عن الزوايا الأخرى. وزاوية غبد الرحمن بدأ فى النمو والتطور أثناء الزوايا

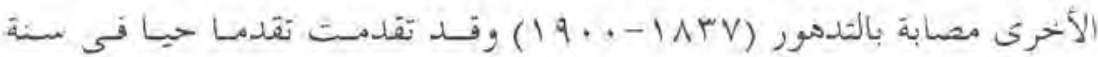

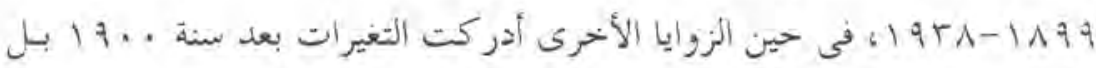
منها صارت مدرسة

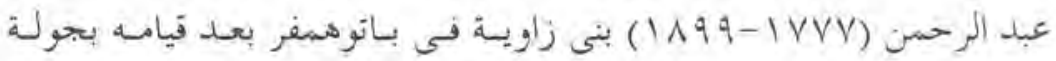

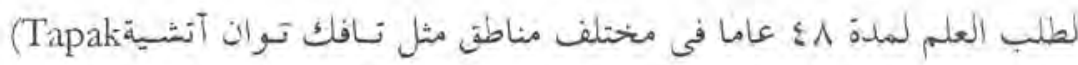

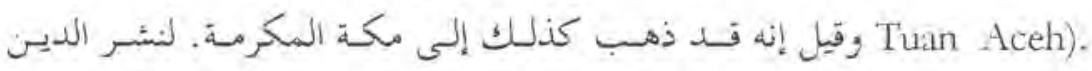

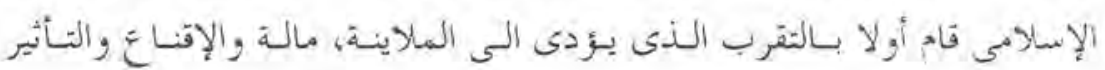

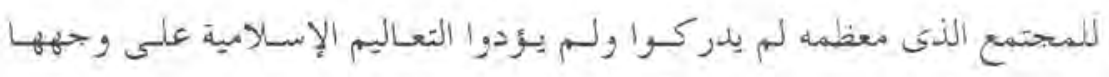
الصحيح ولو أنهم جميعا قد أسلموا اسما.

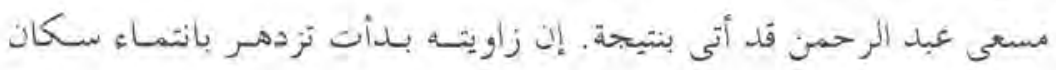

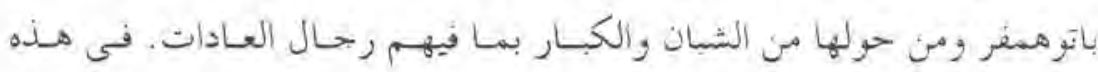

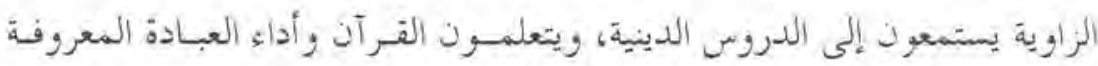

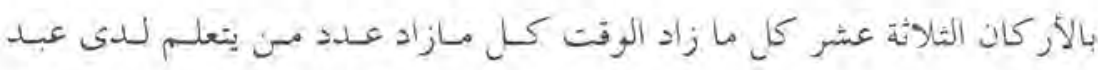

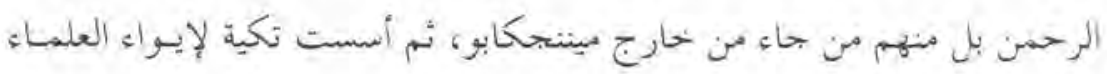
(orang siak)

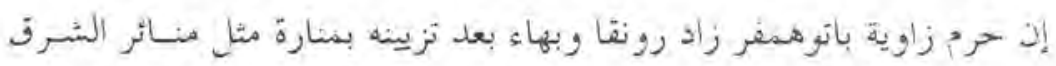

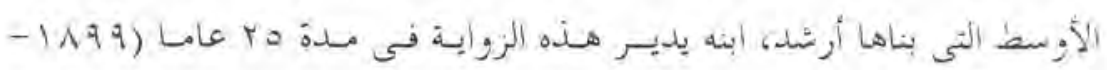

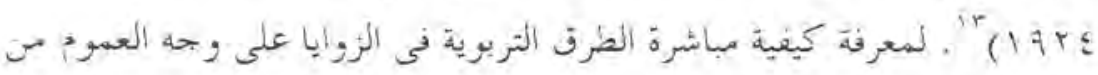

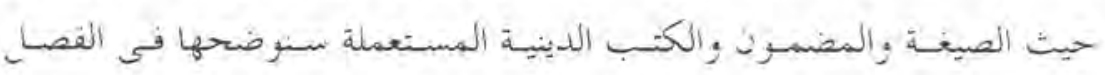

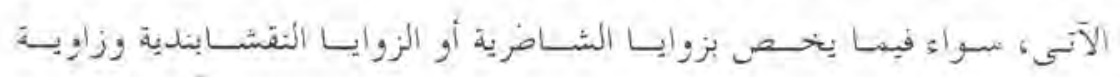

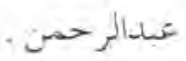


ب- برنامج التربية الذاصة ومضمونها والكتب الاينية:

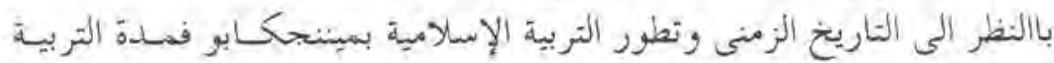

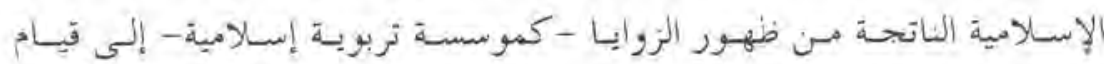
المدارس يمكن تقسيمها إلى ثلاثة عصور يعنى :

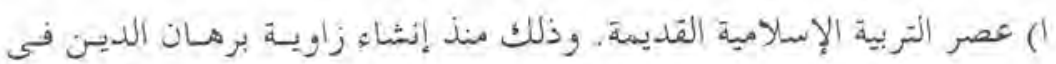

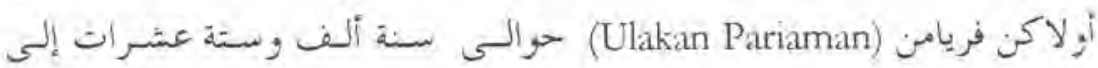

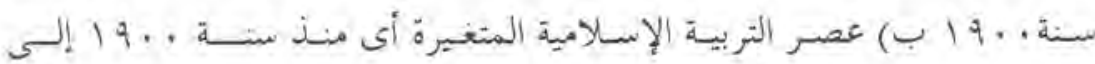

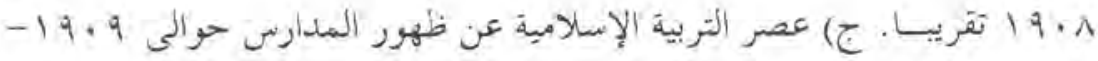

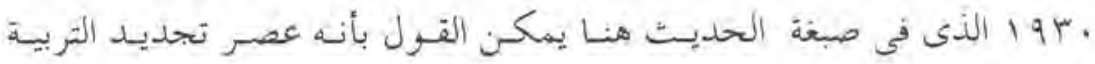
الإسلامبية؛

ولكن خدود ثلأ العهود لم تتطبق على الإطلاق لأن بعض سنوات قبل سنئة

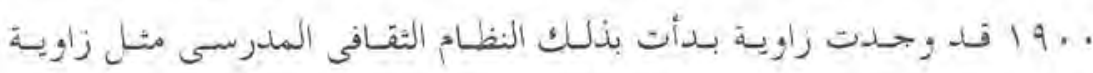

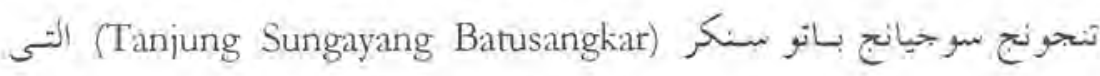

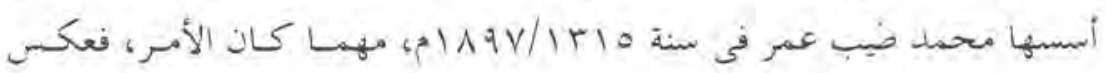

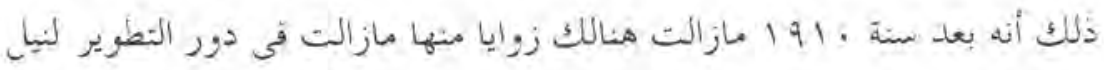

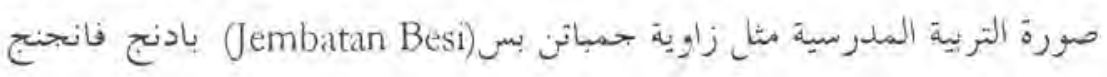

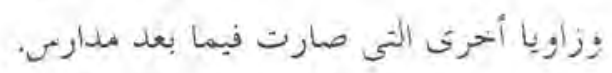

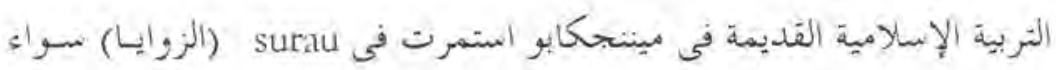

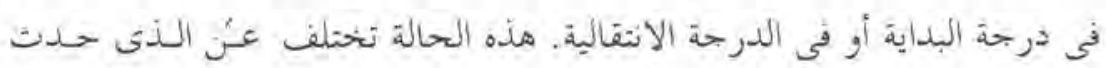

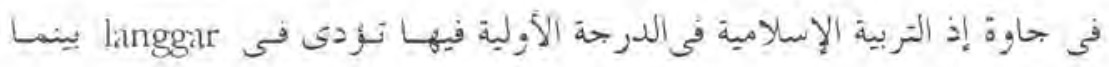

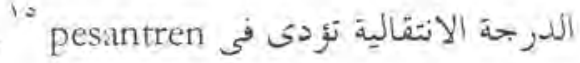


فمؤسسة الزاوية (surau) والمعهـد الإسـلامى (pesantren) ممائلة للنظظام

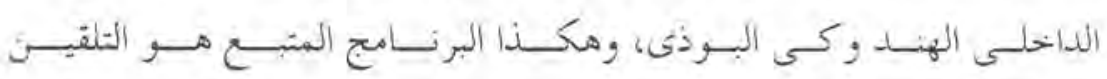

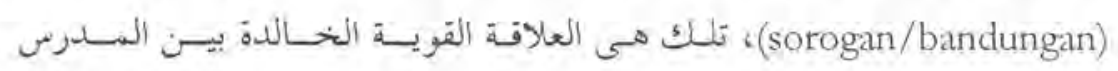
'التلميذ17'

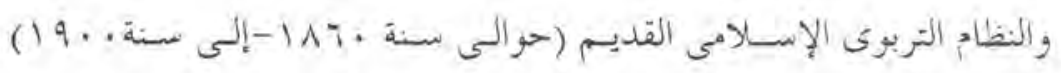

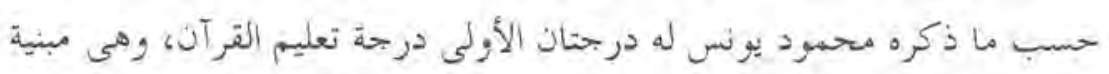

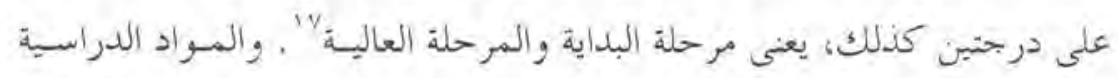

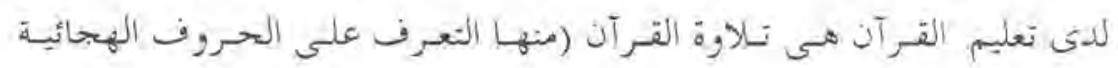

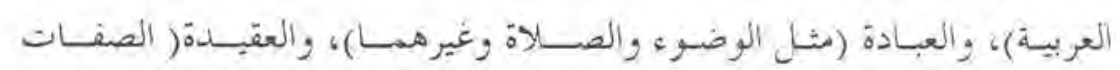

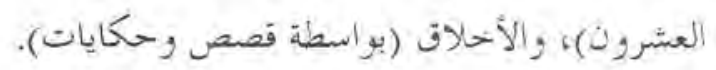

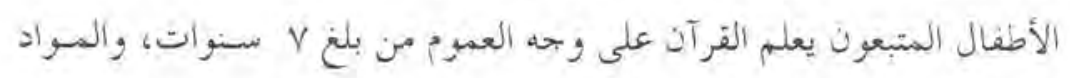

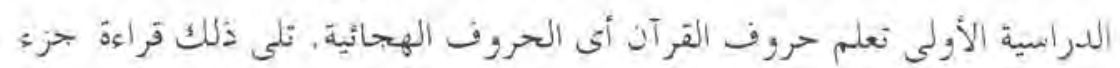

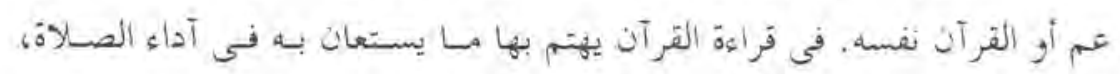

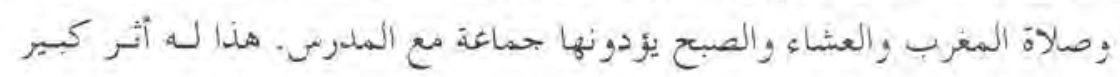

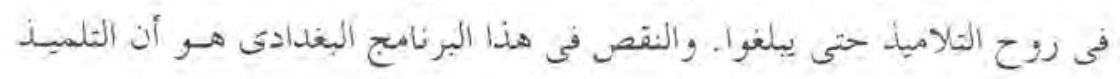

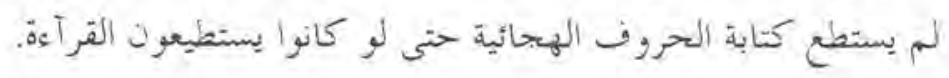

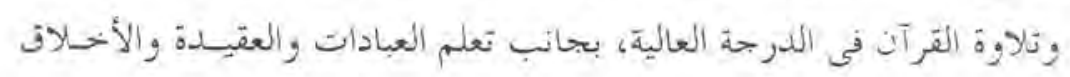

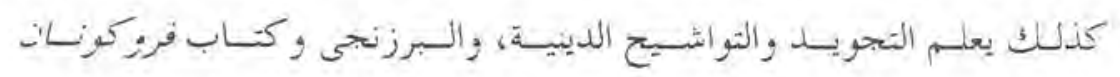
(Pallikernall)

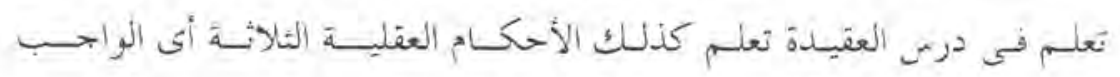

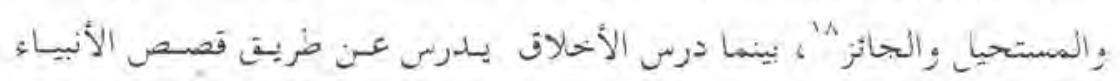

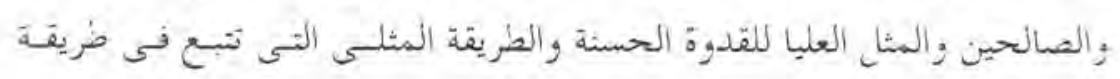

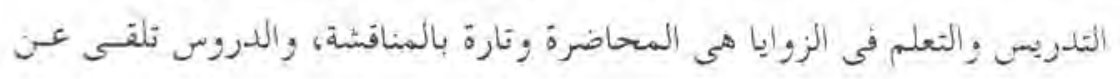




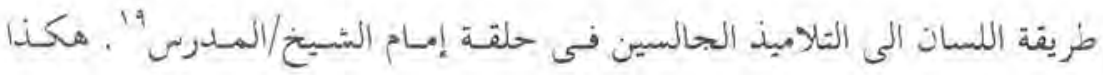

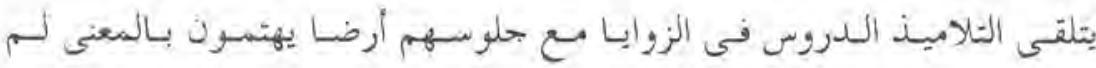

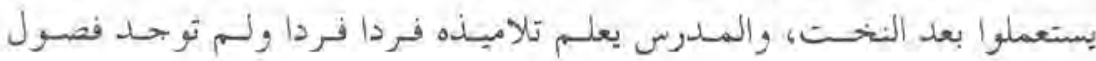
مراسية بعل.

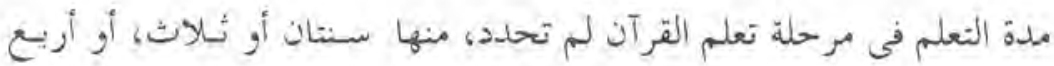

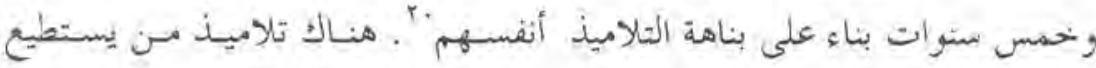
منهم إتحام القبر آن فى سنتين أو ثـالاث سـنوات، ثـم تعـاء القـرائة لتحسبينها ثـم

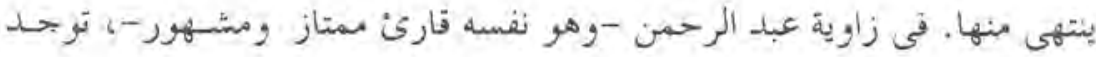
حفلة إتمام القرآة / ختامه كلى سنة مرة. وخدلك كاعتراف بإتمام التلميـذ تـلاوة

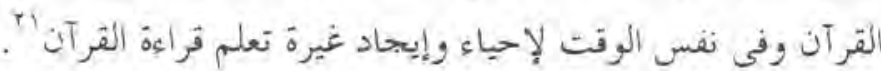

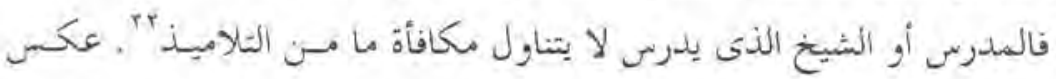
ذلك أن التلاميذ لا يدفعون مصاريف التعليم، فمطالب الحياة بـل واحتياحسات

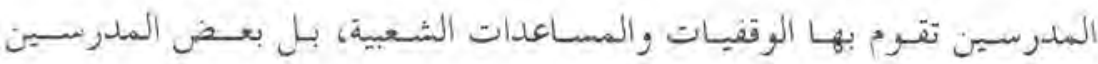
يعتمدون على حاصلات مزارعهم، وأحيانا من هولاء المدرسبين من يعمل في وسي

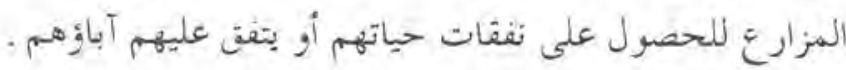
إن نقص نظام التعليم القديم بجانب تطبيقهم نظام البعدادية مثل الذيى قدمناه

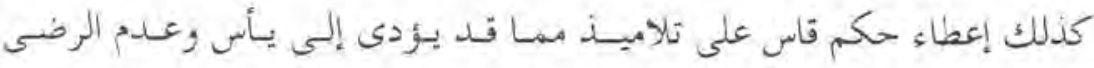
للمدرسين. إعطاء مثل هذا الحكم في نظام التربية الإسلامية القديمة لم يحهدت فى أنحاء الأرخببل الإندونيسى فحسب بل يحدث كذلك فى البـلاد الإسبلامبة

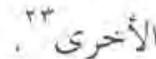

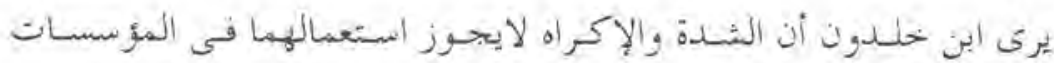

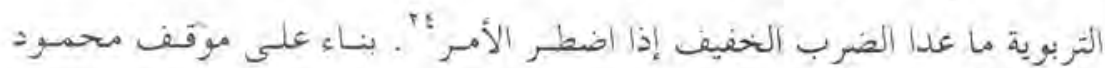

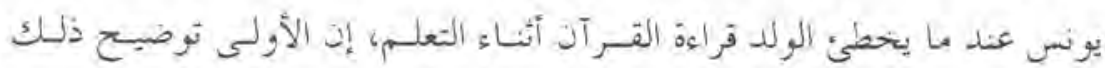




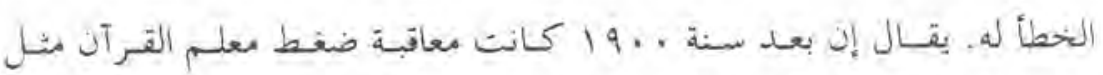

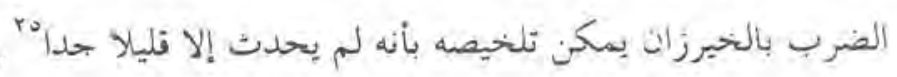

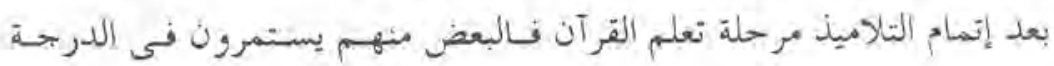

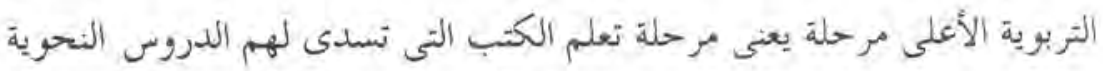

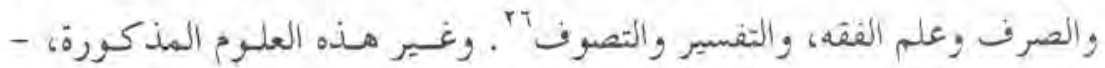

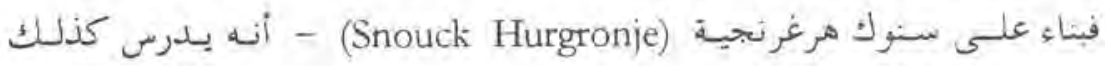

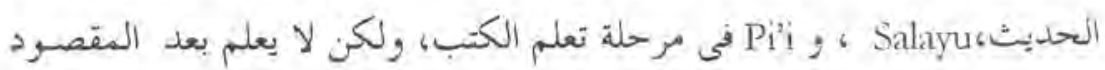

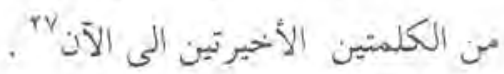

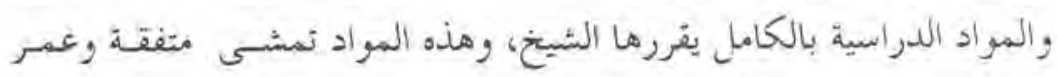

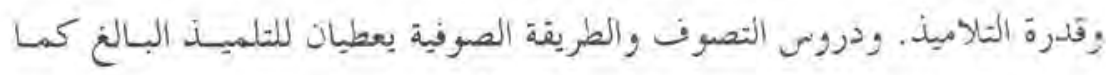

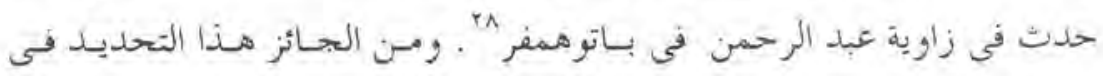

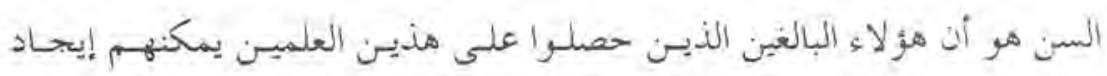

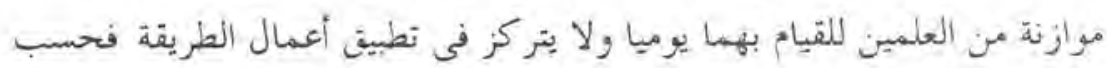
الذى قد ئودى إلى الجمبود.

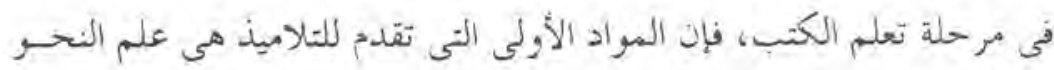

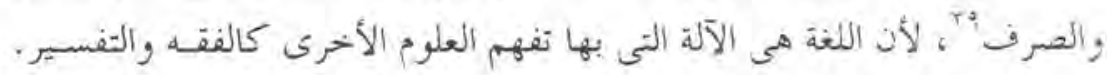

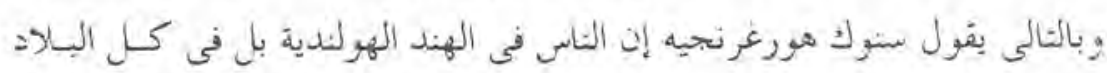

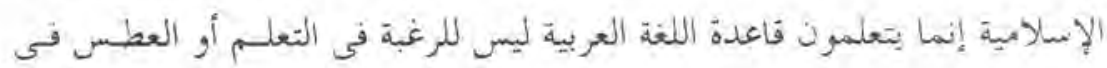

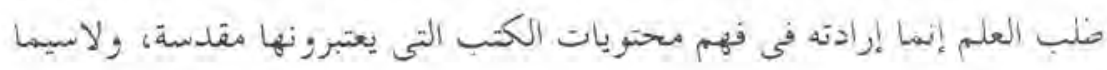

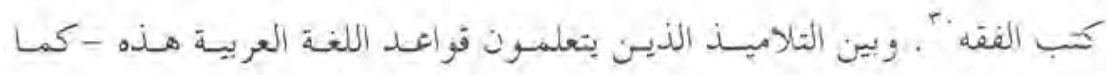

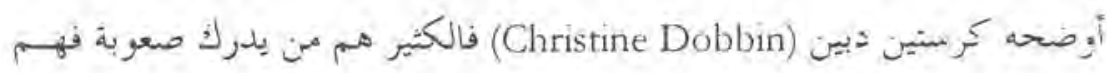

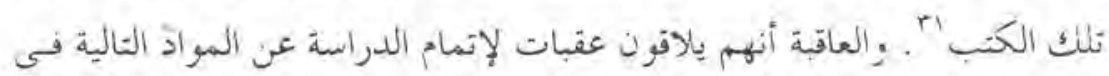
مر حلة نعلم الكتب. 
عند تعلم علـم الصـرف، يؤسر التلاميـذ حفظ تصريف الأفـال وتصريـف الأسدـاء فى كل أجناس التصريفات، والدفردات بع معانى الكلمات في اللغنة الملايوية (المحلية). أما الكتاب الذى يستعمل لتعلـم علـم الصبرف هـو كتـاب ضموان الذى مازال مكتوبـا بحط اليـد، ومسن الممكن هـو من تـألِف علمـاء الأرخبيل لأن من مفرداته توجذ كلمات ملايوية, يقول محمود يونس إنـه تعلـم

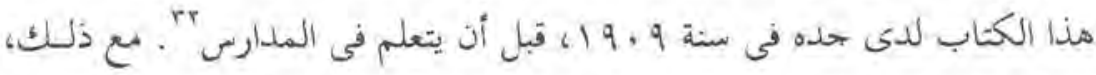
فإن كتاب ضمبرن ما زال يستعمل بعد سنة . .99 1، في الوفت الذّى قد دخلـت التربية الإسلاميية فى فترة التغيير. كتاب ضمون من الجائز إنما يستعمل فى المناطق الملايويسة وبـالأخص في تى مينغجكابو، لأنه لم يعرف بعد المصدر الذى يقول عن أن هذا الكتاب قـد دربى في مناطق الأرخبيل الأخرى. بناء على بياذ محمسود يونس، أنسكتاب ضمسرون

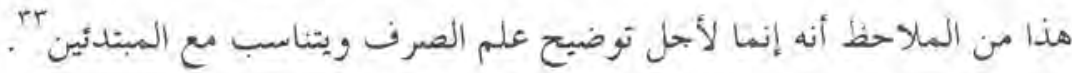

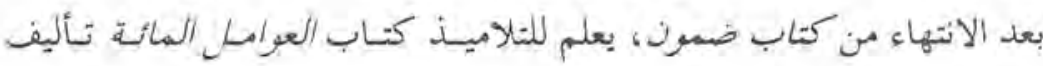

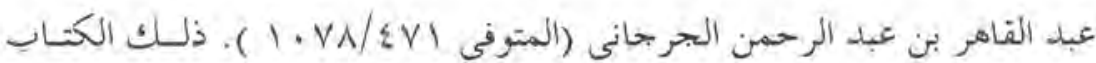

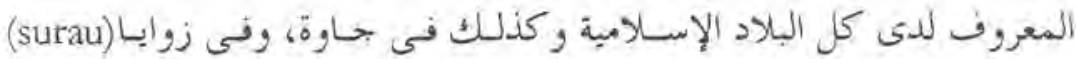

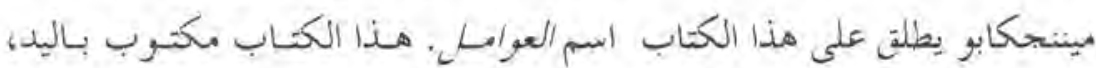
يتكون من نُمانى صفحات، وكل صفحسة سهبعة سطور ويمتلىئ بتعليقات بيسن السطور: ومى شرحه يتعلق بخصوض الفمير والفعل، وحسروف الجهر وأحوال

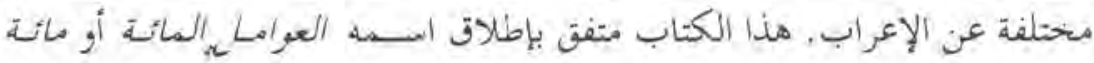
عامل، . ويحتوى على مائة أمثلة عن تصريف الفعلى (الماضى والمضارع والأمر)

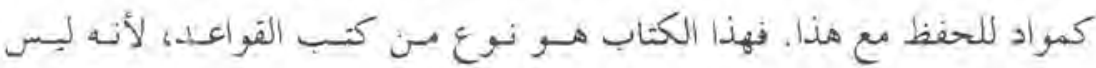
يحمل علم الصرف فحسب ولكن علم النحو كذلك. 
والكتاب التالى لدراسة القواعـد العربيـة في الزوايـا بميننجكابو هـو كتـاب

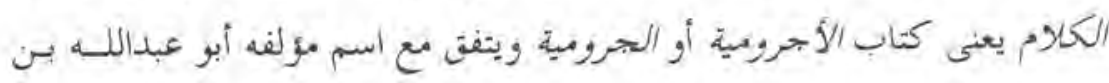

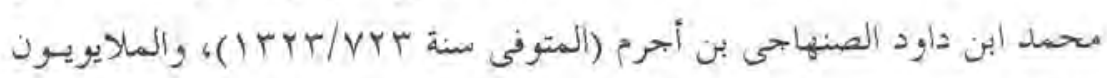

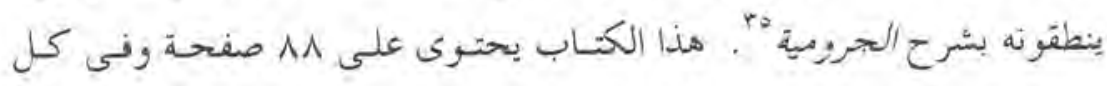

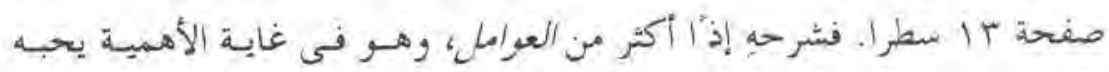

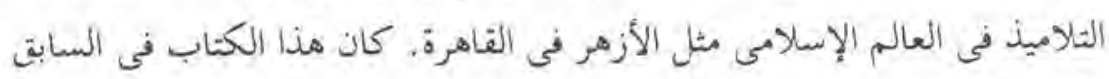

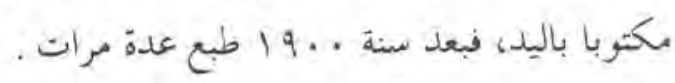

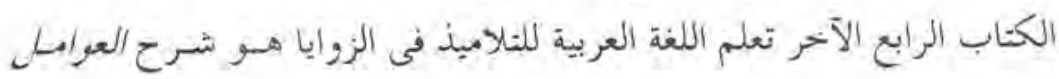

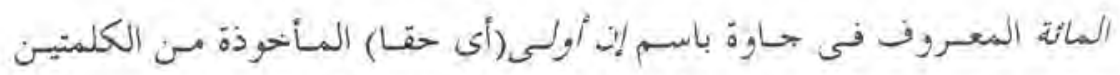

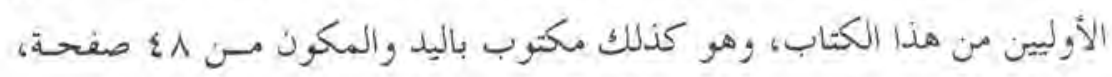

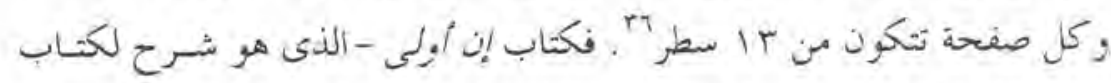

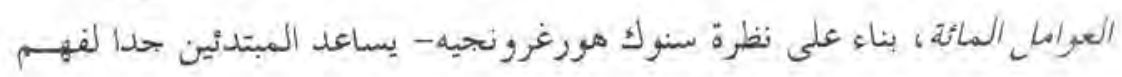

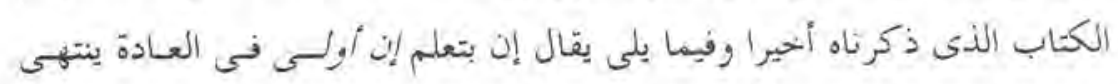

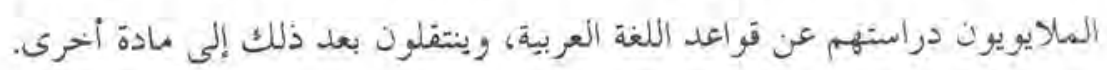
إن التلاميذ الذين أتموا-درس الصرف/النحو فى العادة يتعلمون علم الشريعة.

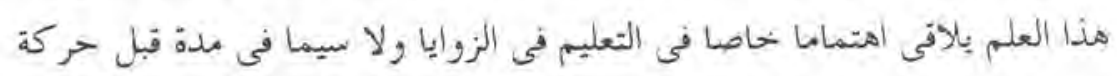

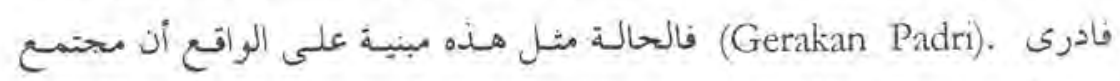
مينتجكابو في نئك الآونة ظاهر وبارز فى القيام بالأعمال المتعارضة مع الأحكاء

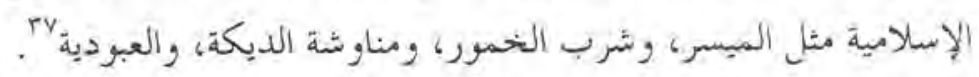

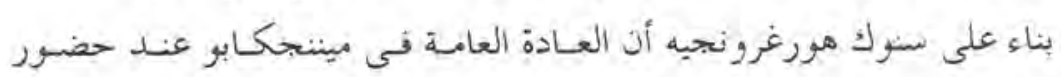

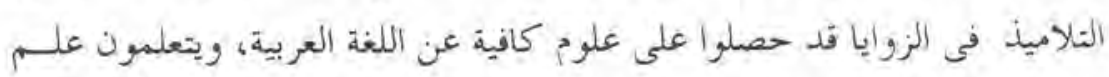

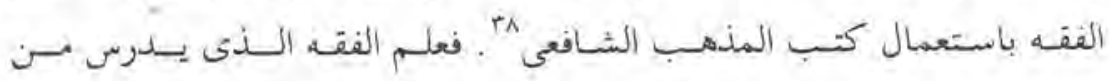
موضوعاته ما يتعلق بالطهارة و العبادة والزكاة: والصور والحج، والنكاح والبيـون 
البيراث قليل الاهتهام بها، هكذا قال سنوك. إذ هذه الحالة يمكن تتعلسق بالبنـاء الاجتماعى لعادة مينتجكابو الأمومية. والكتاب الذى يستعمل فى الفقه فى الزوايا هو كتاب منهواج الطـالنيين تأليف أبو زكريا يحيى بن شرف النووى (المترفى سنة مكتوبا باليد، والمينتجكابويون بطريقة بسيطة يقولون عنه كتاب فقـه أو كتاب

فاقهى خلاف داثرة مينتجكابو، فإن كتاب فقه هذا يستعمل كذلك في جـاوة بـل إلى وقتنا الحاضر مازال يدرس فى كثير من المعاهد الدينية والمدارسى فى أنحساء

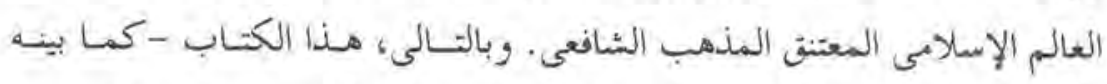

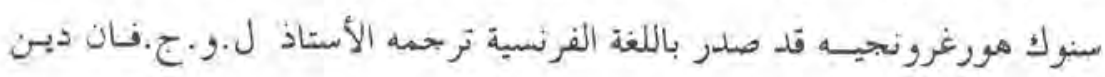
. (L. W. C. Van den Berg) برب وكتاب منهاج الطالبين كبفية الكتـب الفقهيـة الأخهرى قـد كتـب بأسـلوب نثرى عربى متراضع. فبذلك هذه الكتب يفهمها التلاميذ بسهولة، وعلاوة على

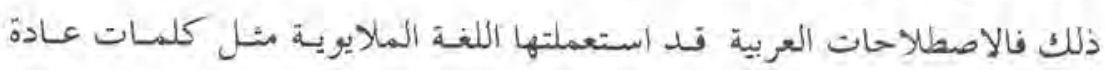
وثرط وسنة وراجب وفاسق ونكاح وطلاق ورجوع.

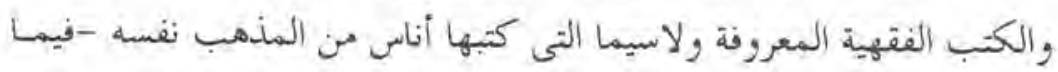
يظهر - لها شكل وتقسيم ورتحتوى كلها متشابه، فلايوجد انتحراف خو معنى.

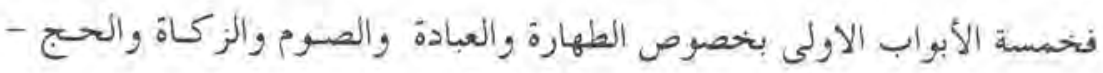
حسب رأنى سنوك هورغرونجيه- أنها تلاقى أكثر اهتمامـا من تلاميـذ الزورايـا،

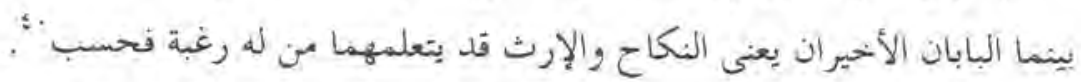

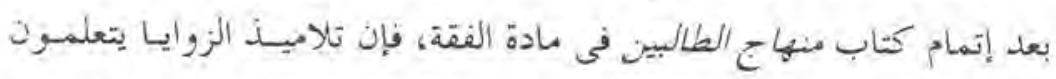

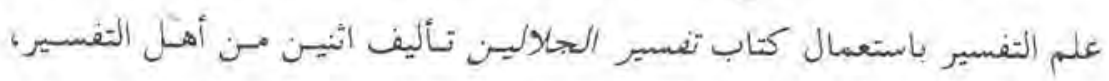

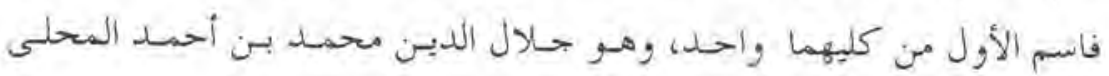




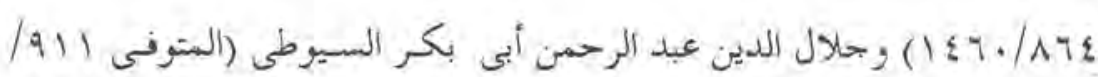

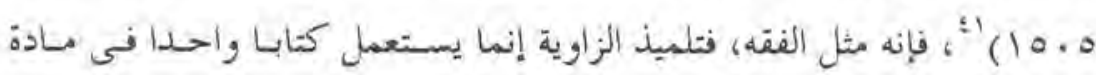

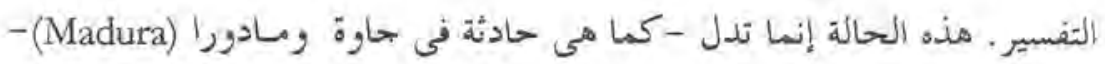

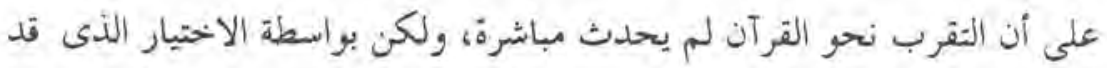
أو جدته كتب أخرى خصوص صا كتب الفقه.

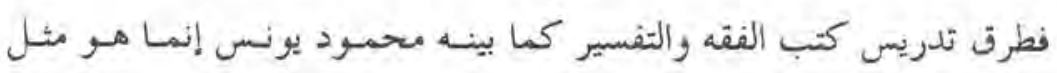

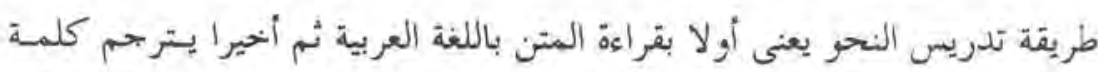

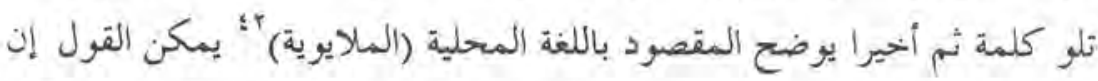

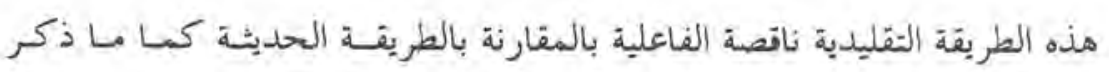
أولا بأنها قوية الثرابط بشخصية ومهارة المدرس، والشيخ أو العالم وما شاكله.

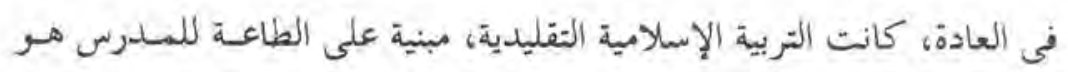

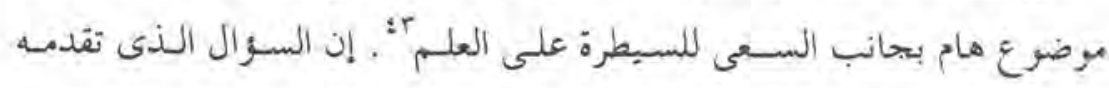

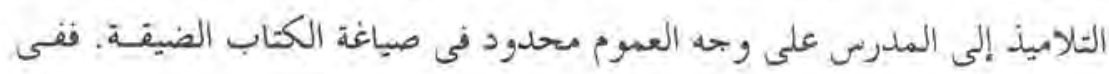

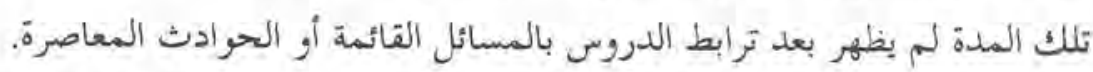

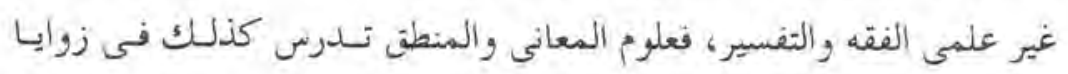

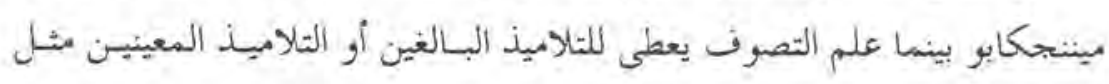

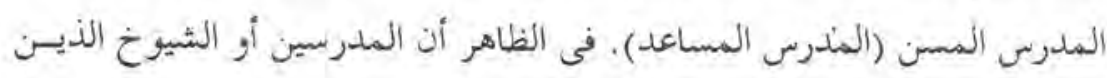

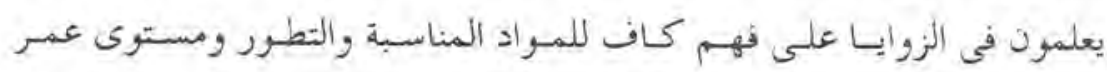

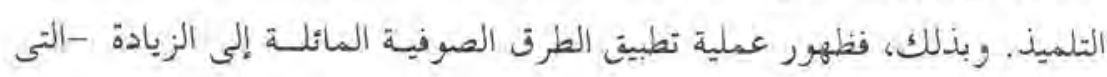

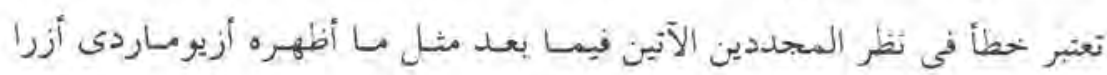

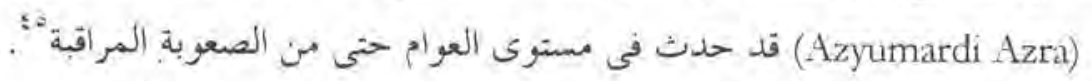

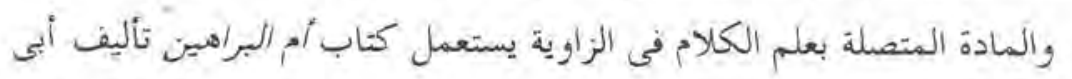

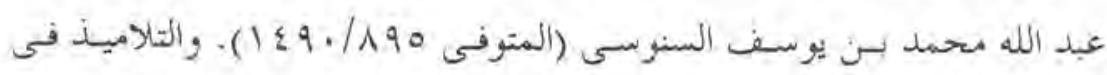




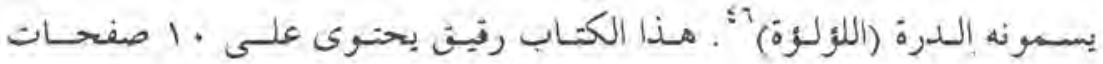
قحسب، ويبين صفات الله وأنيائه بطريقة شاملة. ولذلك يطلق عليه الملايويون كتاب العشّرين صنة (Kifab Dua Pulub) ، وقد صدرت ترجمته باللغـة الألمانية

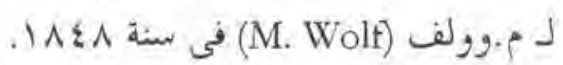
في مجال التصوف بستعمل كتاب الفتوحات المكية تـأليف محى الديسن بس

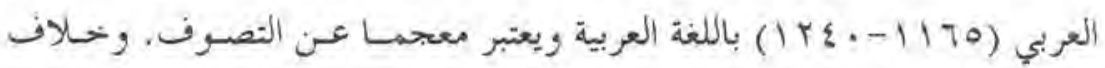
ذلك، يستعمل كذلك كتاب التحنة المرسلة الى روح النبى الذى تحت كتابته،

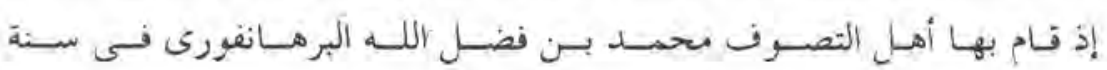

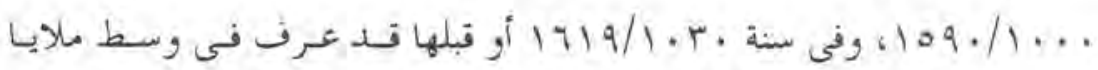
والأرخبيل الإندونسى، ثم كتاب آخر بـدرس عن التوحيد عبن سراه تأليف

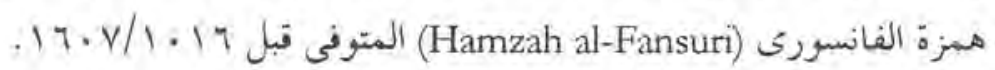
رغم ظهوره في دروس التصوف فى الزوايا المتعلق بتعليم وحدة الوجود لابن

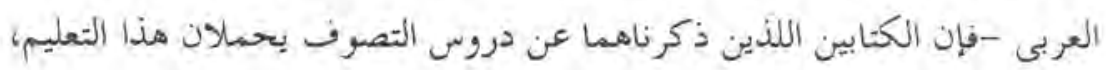
ولكن لاتوجد حقيقة تشير إلى أن التصوف المؤدى إلى وحسدة الوجسود منتشـر

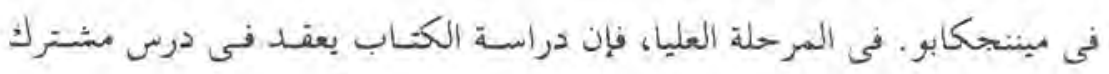

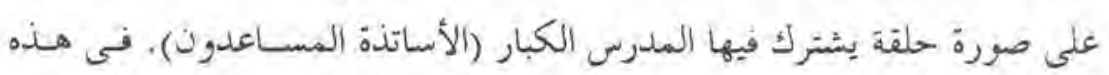
الحلقة العلوم التى درست مثل الفقه والتفسيرتعاد للتعفثى فى فهم المواد. على أسـانى جملـة الكتـب التى درسـت في زوايـا مينتجكابو على وبهـ

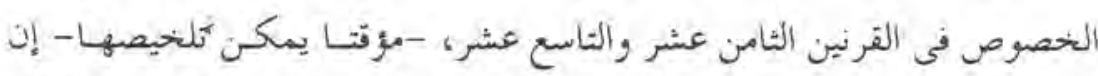
الكتب العربية غاية فى القلة تدرنى، بينما فى تلك الآونة قد بلـغ تـأليف العلمـاء

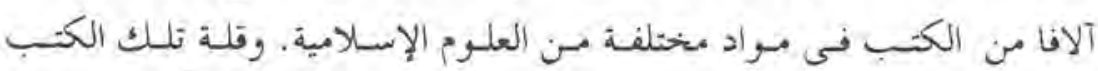

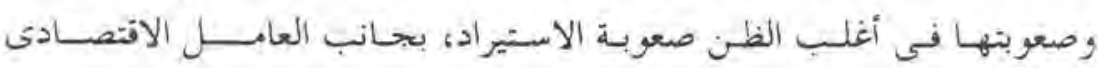
والميانى النيى لم يثكفل أستحضاروها. 
أما الكتب الدراسية باللغة الملايوية وبـالخصوص فى القرئين السـابع عشر

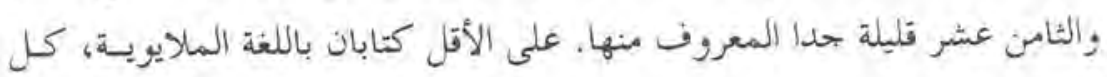

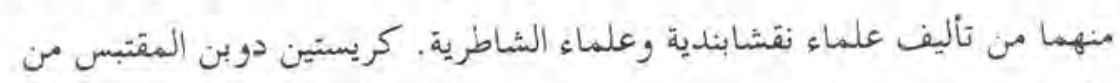

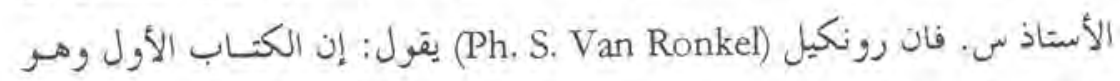

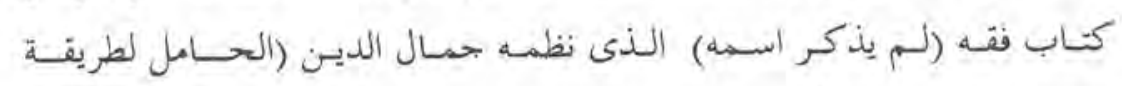

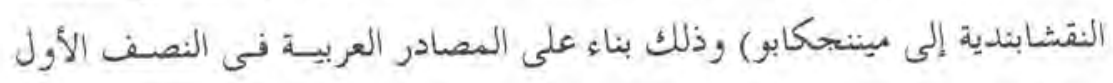

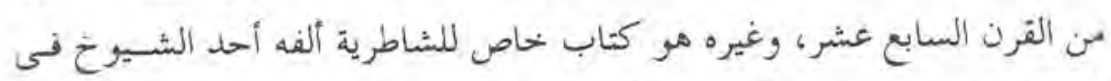

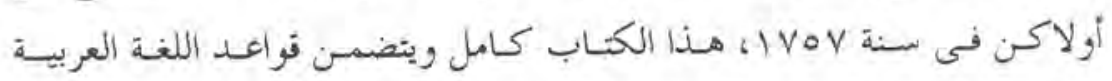

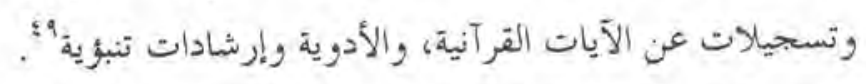

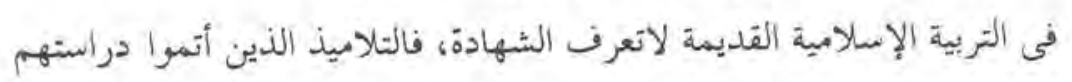

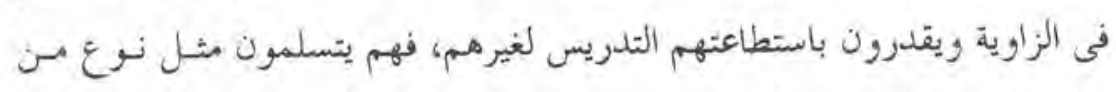

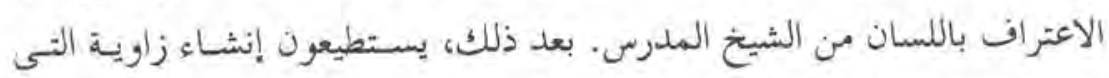

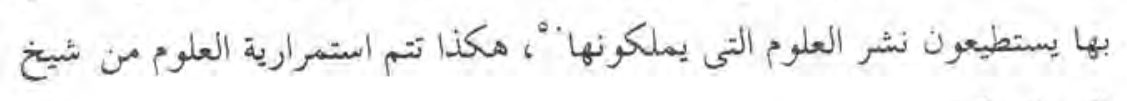
إلى نتاميذه.

بالنظر إلى الاجراءات التربوية الجارية فى الزوايا إلى آخر القرن الثامن عشـر

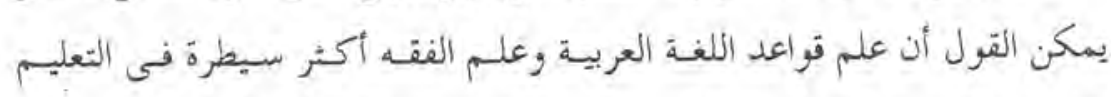

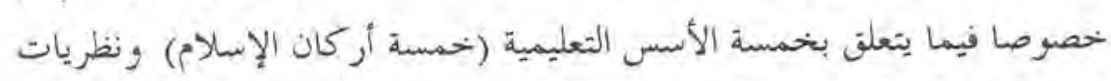

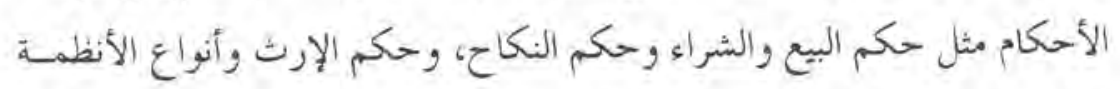

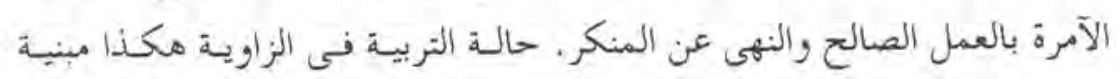

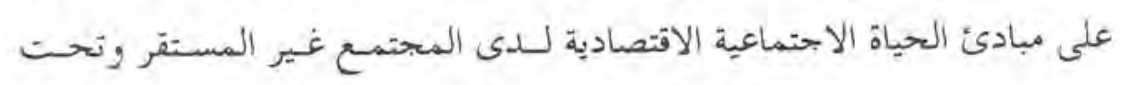

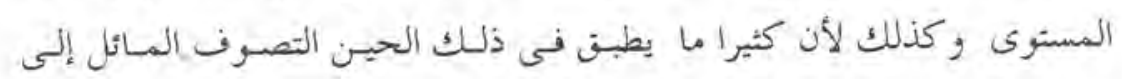
الإسراف. 
أو الذين تسلموا الخلافة منه -وباسنمراز إلى الخلف - ومن بيسن هئلاء الأكثثر

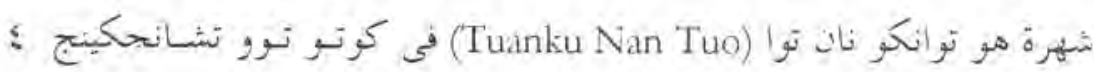

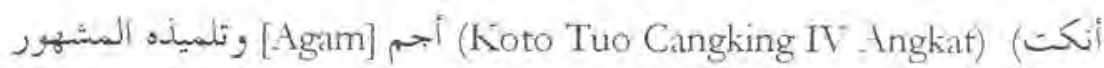

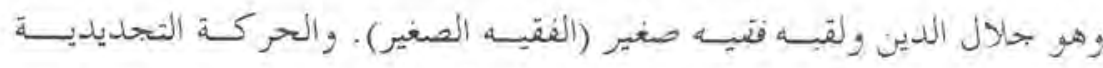

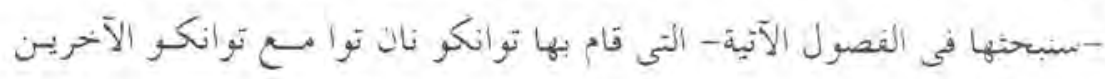

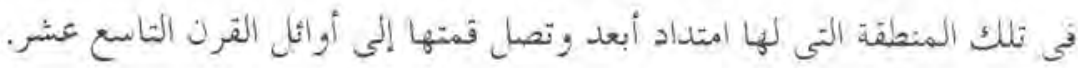

ج- الزاوية وحركة الوعى الإسلاهى فى آواخر القَرن الثُامن عثر فئر

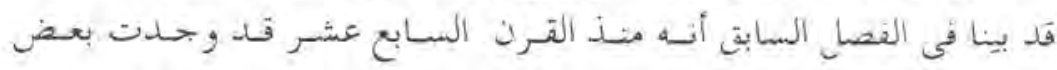

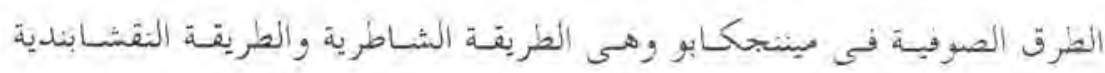

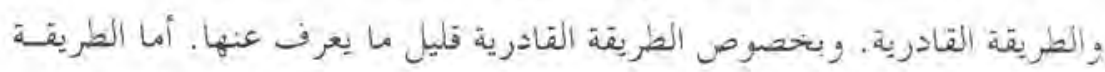

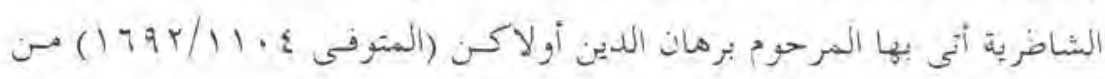

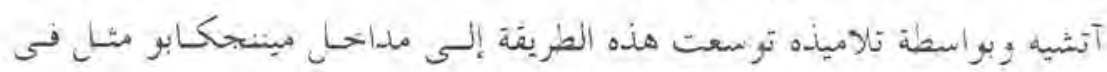

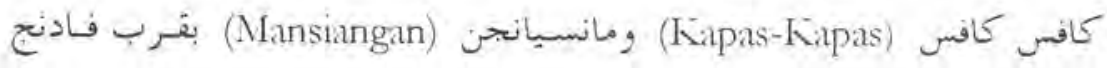

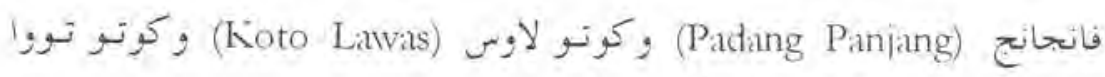

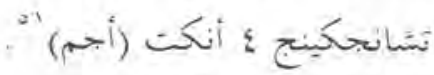

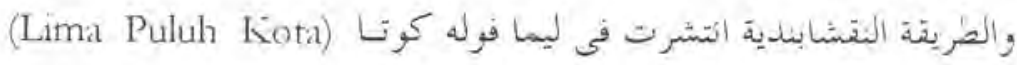

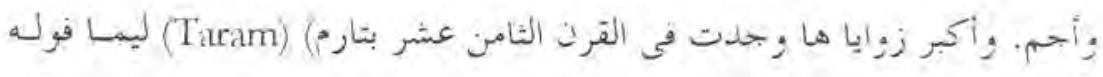

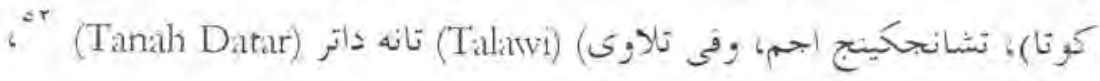

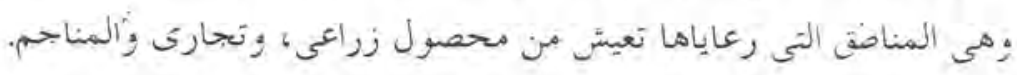

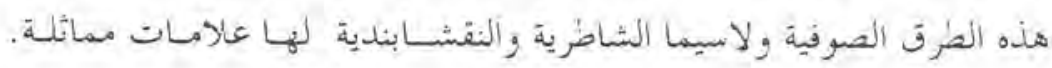

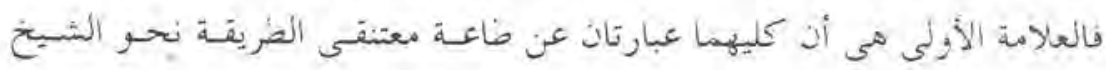

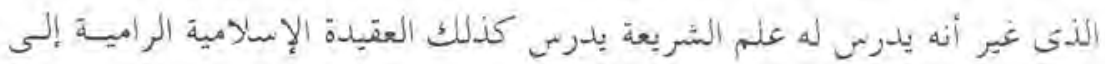

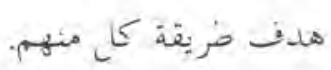


وفى تطور الطريقة الثالى هو أن بعض معتنقى الطريقة ولاسيما هـولاء الذيسي

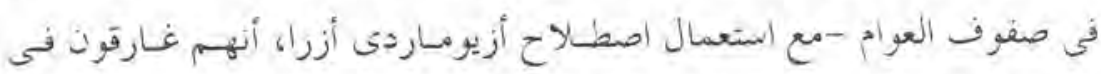

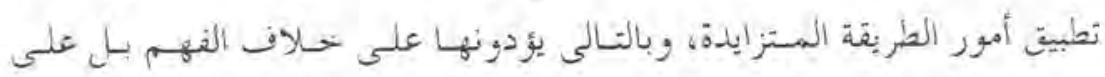

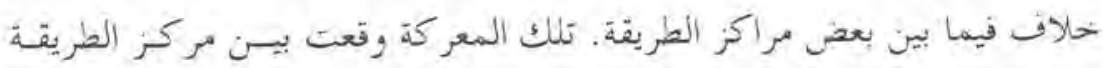

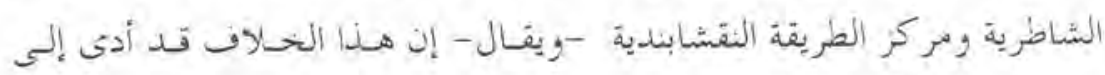

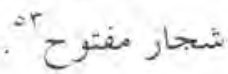

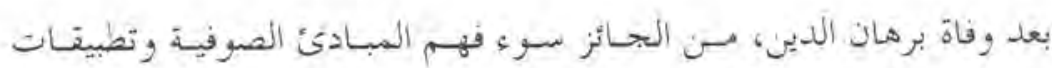

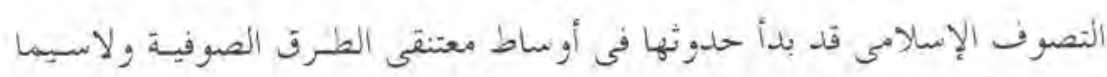

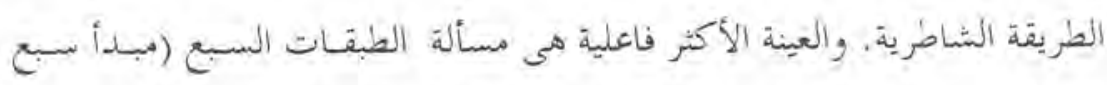

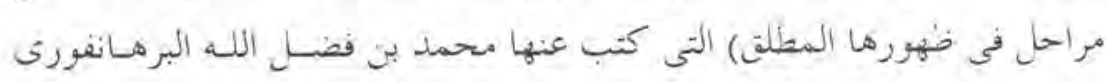

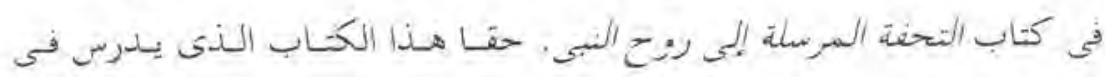

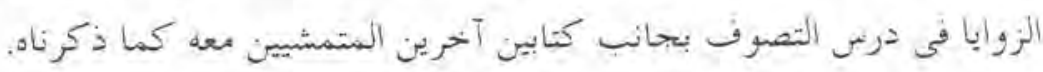

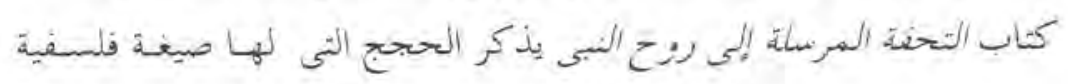

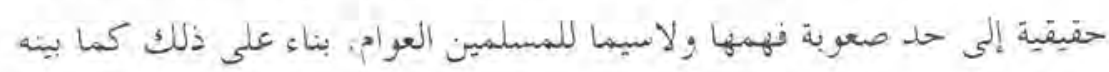

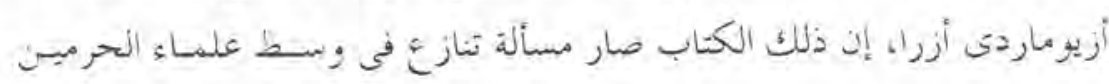

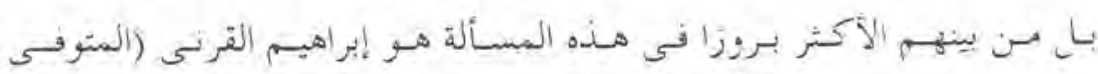

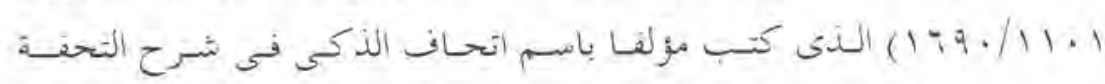

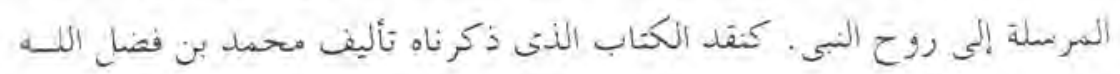
البرهانعورى"

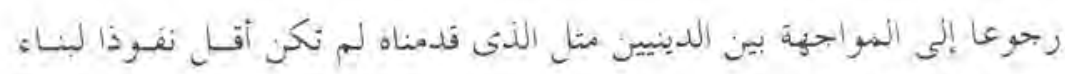

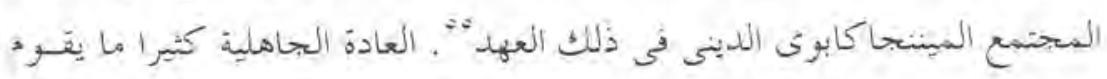

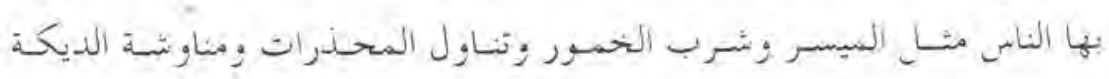

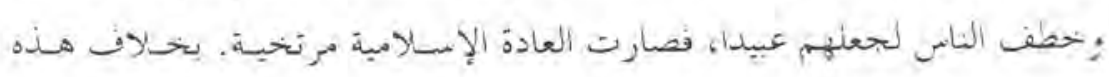


مبالاة بعض رجال الدين الفارقين فى الخلافات فيما بينهم، فإنه كنلك من أجل

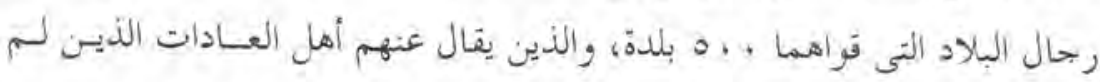

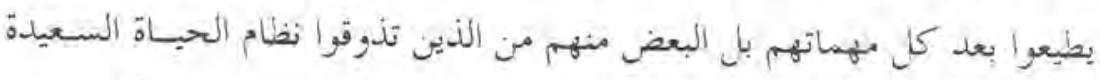

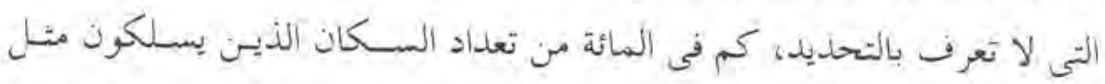
هذه الخطة اللا أخحلاقية. إذا ما كاثوا هم الذين يقومون بهذه الأعمال المنحرفية

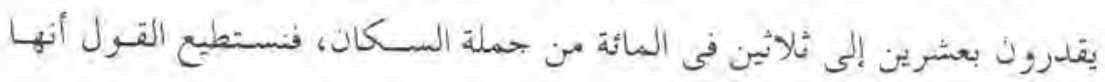
مسألة عادية فى نظام جياة المجتمع الاجتماعية فى تلك الآونة.

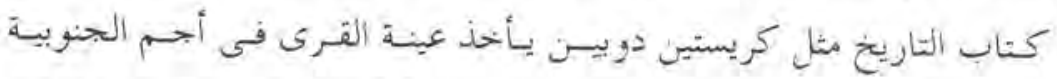

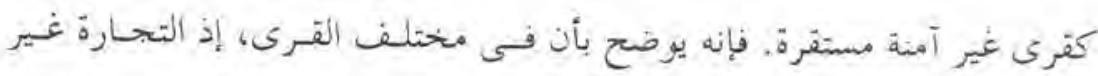
منظمة بدقة، وفطان الطرق فى حرية، والتجار يخطفو ن. السبـرق ذات الاعتبـار

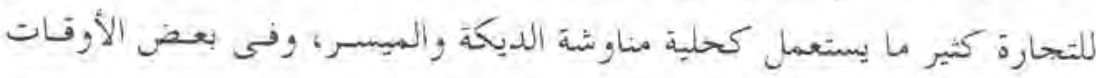
كمربط بائعى المحذرات والمسكرات من من ناحية أخرىى، ومجلس القرية عـاجز

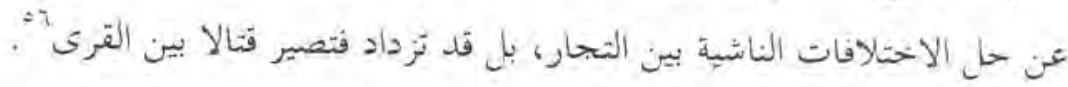

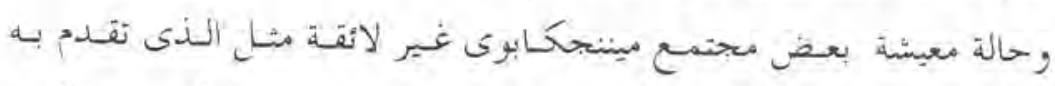

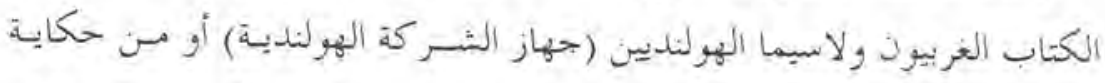

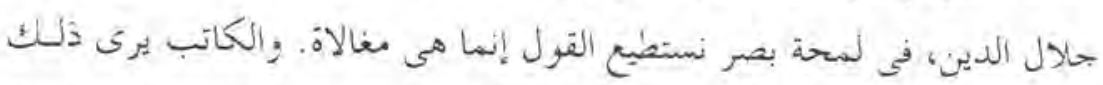

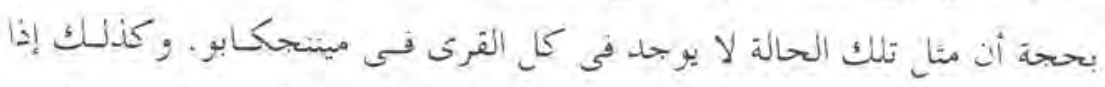

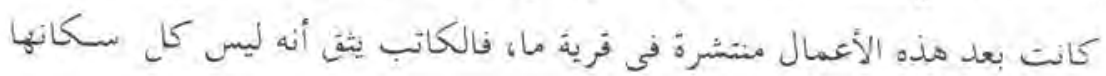

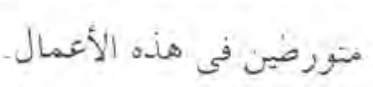

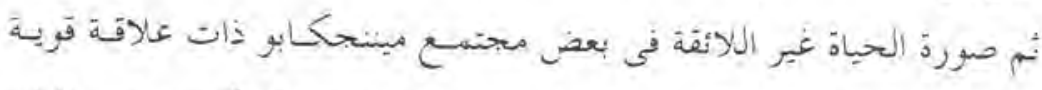

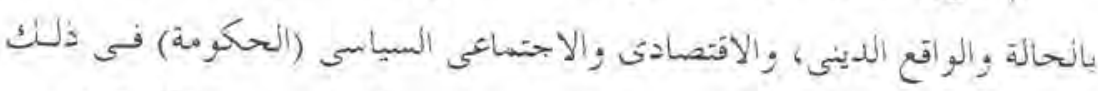

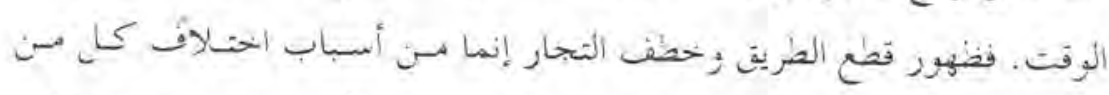

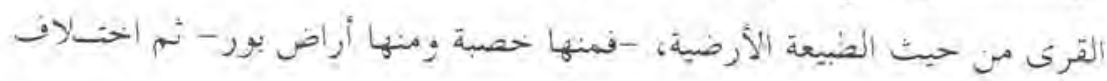


المحصول الانتاجىى لكل قرية مثل القرى التى يمر عليهـا التجـارة التيى تحسدث فيها كل الأشيطة، فنكون أكثر عمرانا بالمقارنة للقرى المنعزلة.

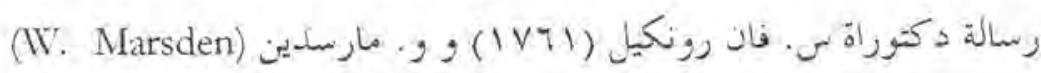

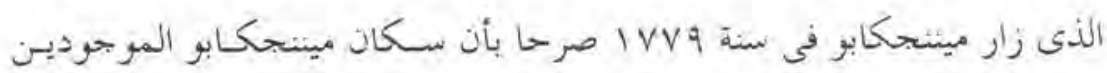
على وجه العموم قد اعتنفوا الإسـلام، مـا عـدا مثبعى الطبرق الصوفيهة وزعماء

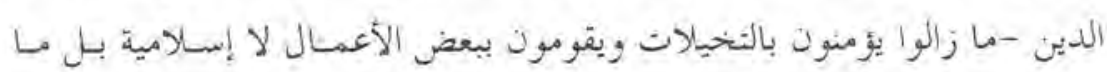

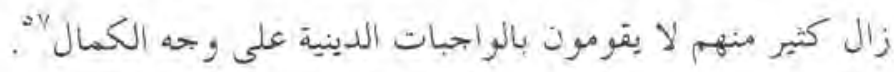

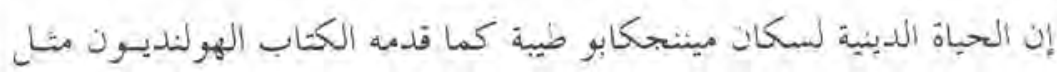
: مارسدين (The History of Sumiatia, p. 3+6) وكذلك جلال الدين فى كثابه حكاية جلال الدير ص. 1، يسكـن فهمها، وكذلـك الملاحظة في أن الرعساة الناشرين للتعاليم الإسـلامية في مينتحكابو والمنتيسن إلىى الصوفيسة، يتعـاملون

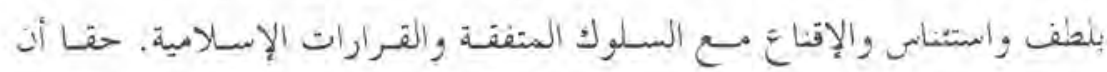

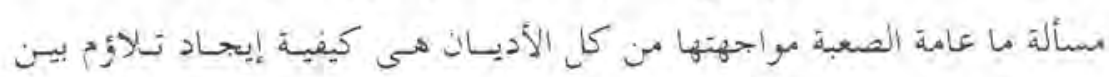
البيئة الموجودة فع المبدأ الدينى. الحكومة (نظامها) هو العـامال الأكثر إيجانبـا في ثقريسر الأمسن لولايبة مـا. فبذلك كيف يتفق النطاء في مينتجكابو في القرئين السـابقين حيست نوجسد

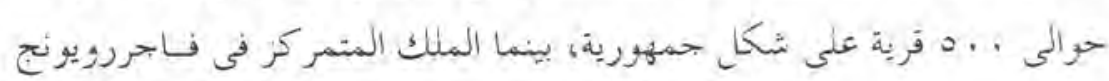

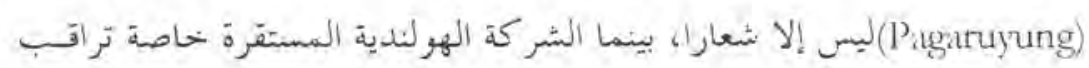

$$
\text { للبحث عن مكسب أكبر. }
$$

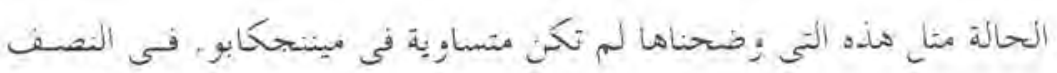

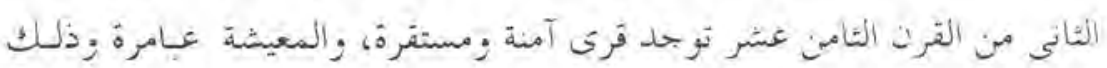

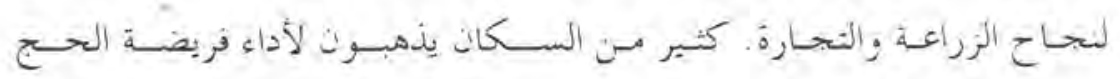

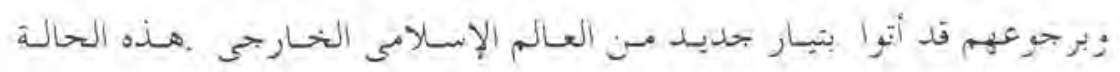


بركة التعاون الطيب بين العناصر ذات العلاقة في داخـل البلاد الثتى اصطلحسوا

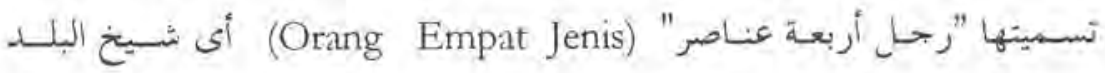
(dubalang) وكشرطة القبيلة والعـالم (Penghulu)

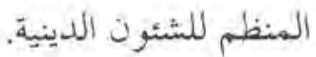

القرى المعمورة مثل تارم (Taram) (ليثـا فوله كرئا) وتنالاوى(Talawi)

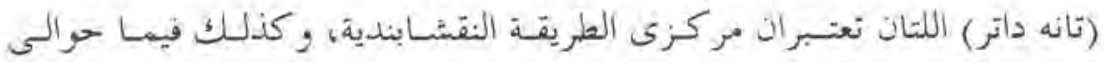

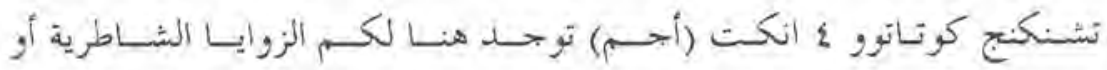

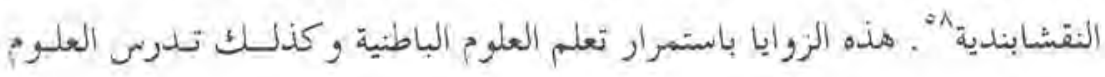

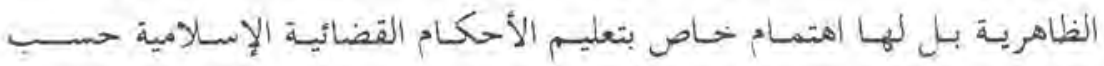

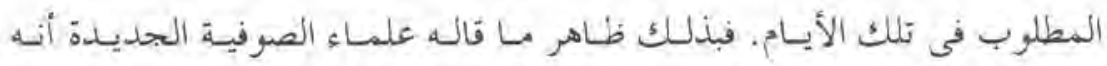

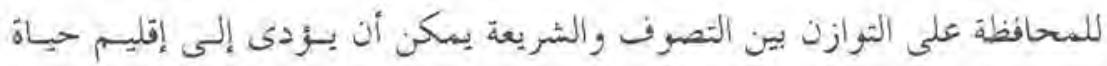
الأكثر لياقة للأمة الإسلامية.

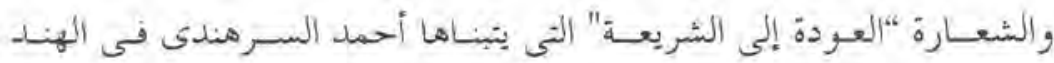

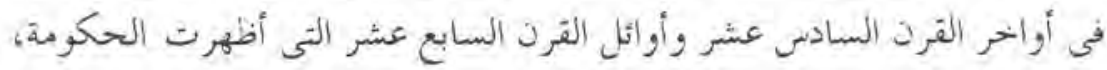

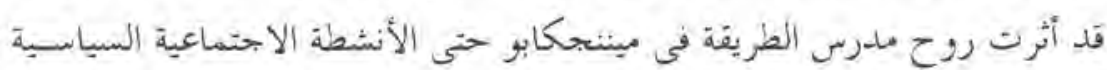

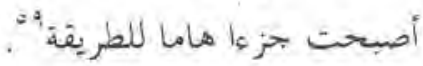

ففى هذه المساعة هذا الوضع لأول مرة في سوبطرة الغر بية قد أعسدت نفسها

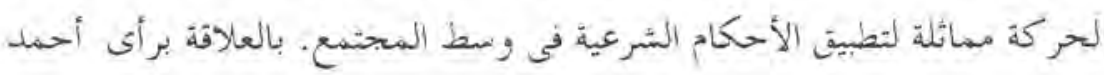

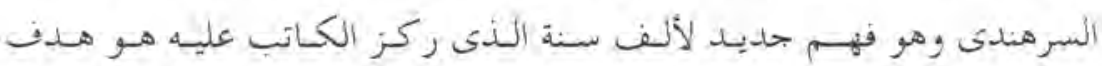

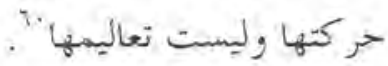

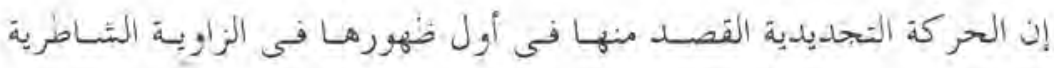

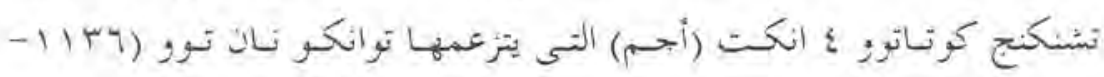


بناء على كتاب حكابة جـالول الديس، اللذى كثيرا مـا ينقل عنه البـاحثون

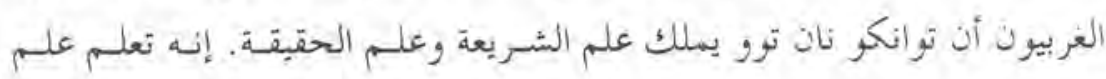

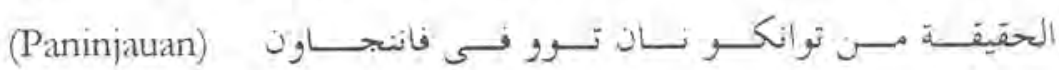
ومانسيانجر (Mansiangan) وأخذ علم الآلة (قواعد اللغة العربيـة) عس توانكس

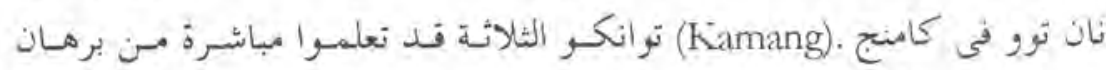
الدين أولاكز

بالنظر سبلسلة نسب مدرس توانكو ناد تور كوتو تور ع أنكت التى بدى

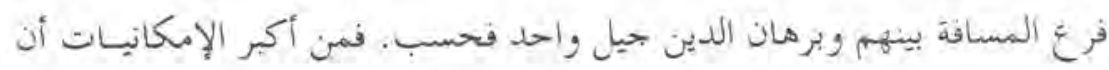

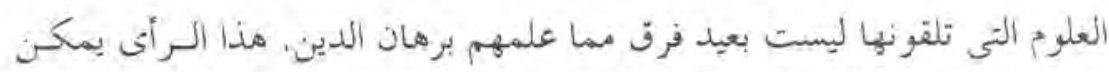

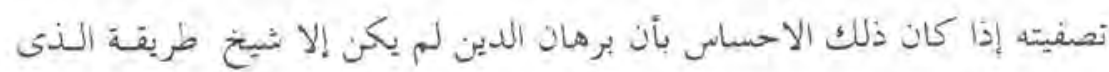
لا يهتم بالشر يعدة.

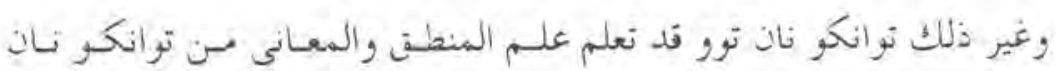

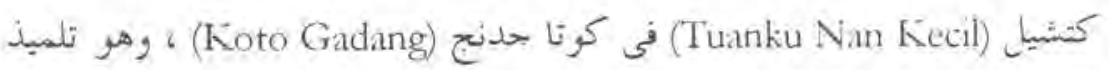
تو انكر في تمفانج راو (Tampang Rao) الذى أتى من مكة، وبعد ذلك ثو انكو

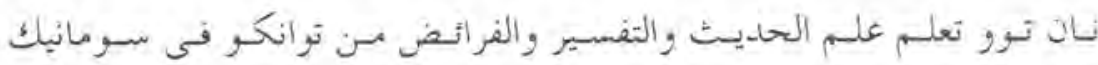

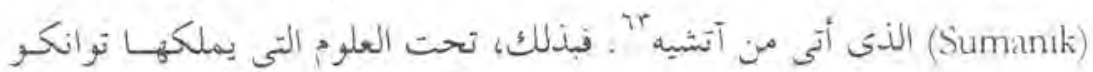

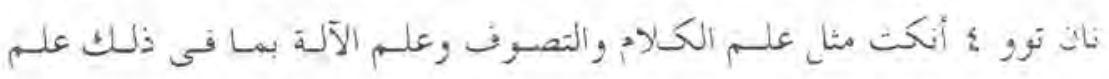
المنطئ والمعانى بع علم الحديث رالتفسير والفقه منه الفرائي.

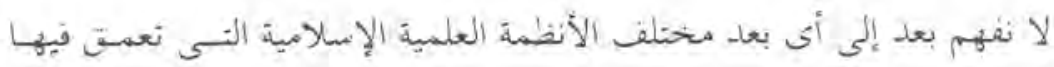

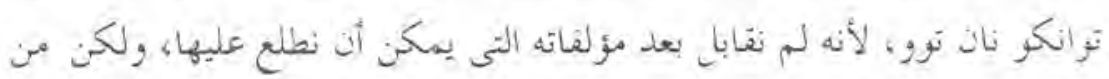
اليقين البعلق أنه أحد الشيوح العالم فى مختلف العلوم الإسلامية.

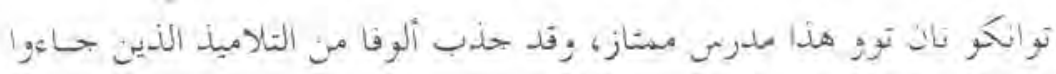

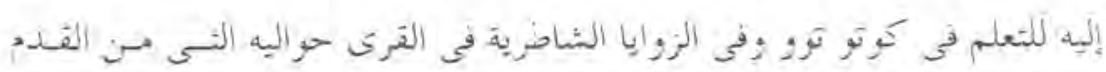


قل الختلطت في سلام فى المناظر الزراعية. وزاوية توانكو نان تور فى عبارة عن مركز الطريقة وكذلك مركز لتعلم الففه الحامى لكل الأحكام الإسبلامية سواء تلـك التى لهيا صلة بالواجبـات الدينيـة أو متصلـة بمختلـف أنسواع الحيـاة

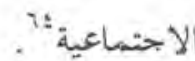

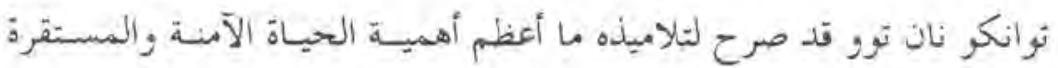
لتكوين الاتحاد لمجتمع مينتجكابو، فلهيذا قد علم لهم مشتلف الأنظمة الثتفقـة والتعاليم الإسلامية ولاسيما الثى لها صلة بالأحوال الكثيرة التساؤلات مثل البيـع ; الشراء و الطلاق والتركة"

وتوانكو نان توز لا يقتنع بالتدريس في الزاويسة فحسـب ولكنه كيون وفــا

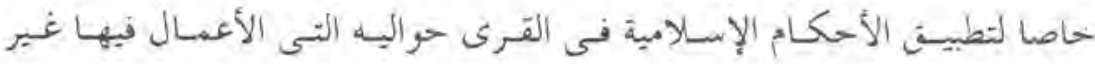

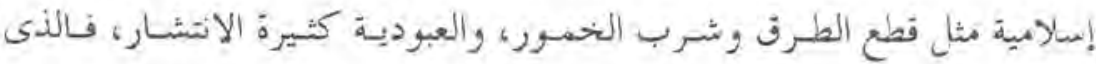
يتورط فى هذه الأمور يحاكم إلى النهاية، ثم يفنعهم بقبسول المبـادئ الإبهالامية الحمسة، ولأجل أن بعيشوا مثل المسلمين الطيبين ونتيجة ذلك عاد السلام إلى لى

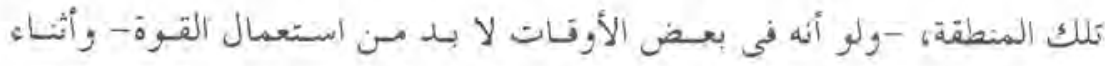
حلول منتصف سنة . V V نالت منظقة ع أنكت (أجم) انتصارا هائلا في تنظيم الأمور التجارية. ثوانكو نان تور كأحد التجار كذلك الماهر عرف وكأثه مركز

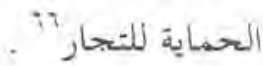

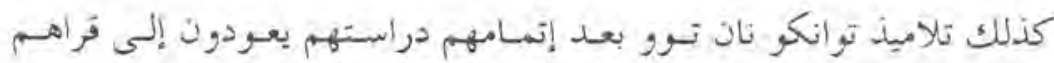

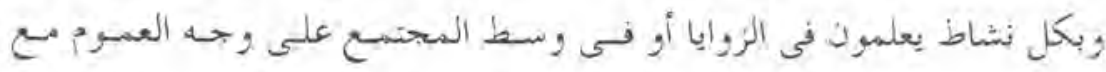

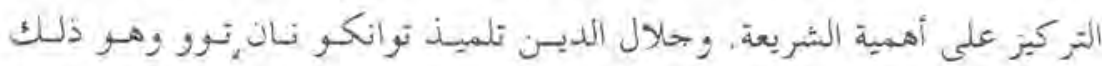
المشهور قدل بنى زاويته في كوتو لاوبى فادنج فانجانج التى من قبل قل وجهلت

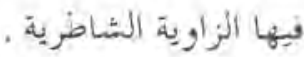




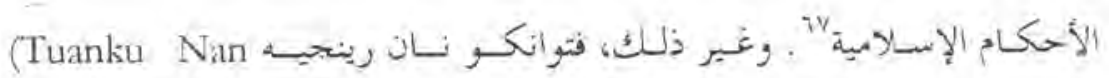
Renceh) (1772-1832)

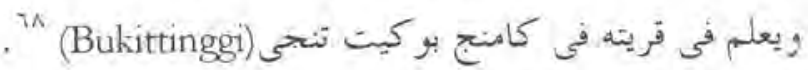

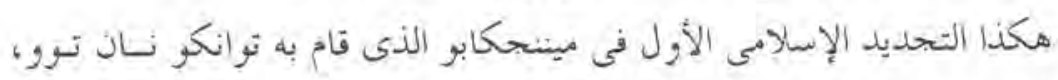

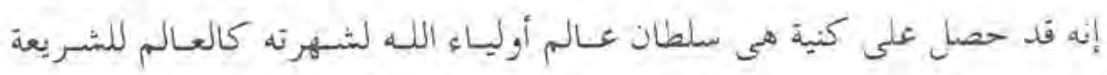

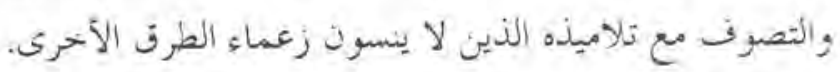

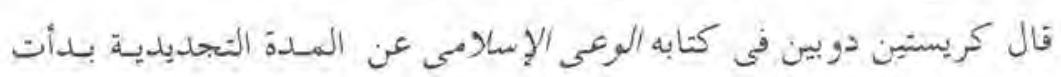

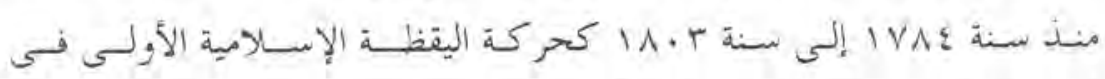

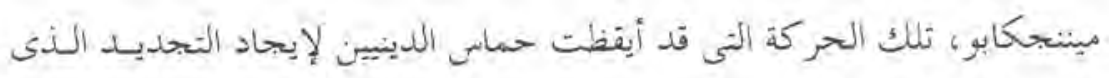

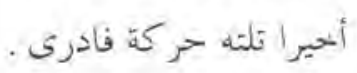


"The Rise and the Decline of ،(Azyumardi Azra) 1 أزيوماردى أزرا the Minangkabau Surau: A Traditional Islamic Educational Institution in West Sumatra during the Dutch Colonial Government"

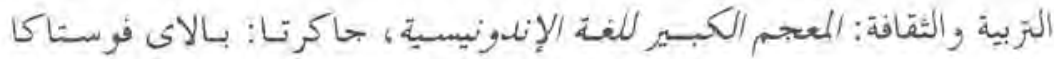
(Balai Pustaka)

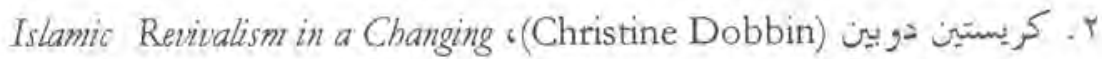

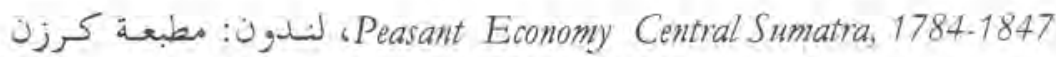

$$
.1 Y 1-1 T \cdot .0619 \lambda r \text { [Curzon] }
$$

Mesjid Pusat Ibadat dan Kebudayaan،(Sidi Gazalba) Islam (Pustaka al-Husna)

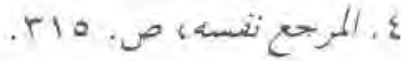

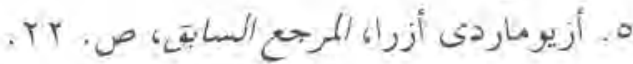

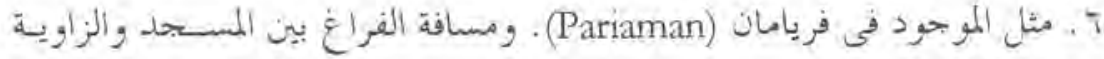

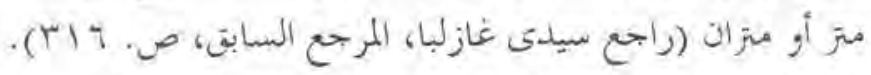

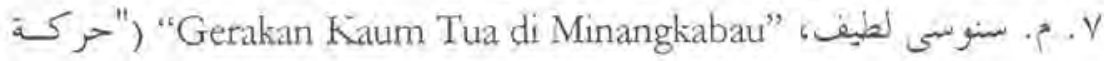

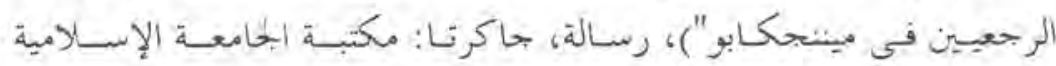

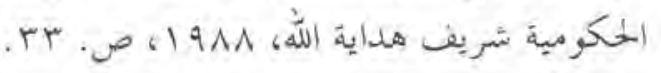

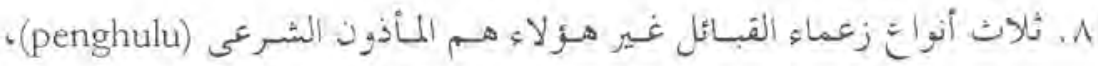

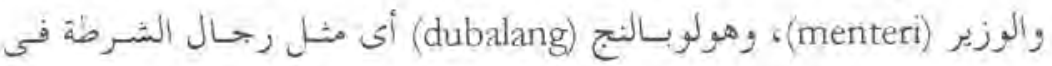

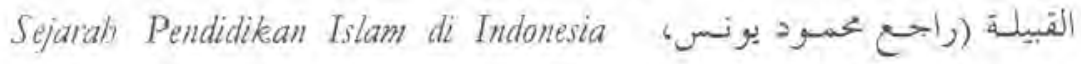

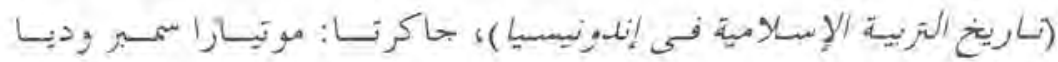
(Mutiara Sumber Widya] 
واصطلاح مالِم (malim) من أصل عربى (معلم) ومور الشخص السنى بعلسم

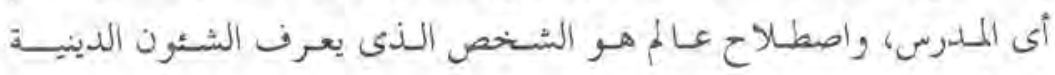
الإنسالمية.

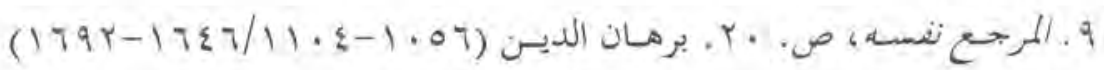

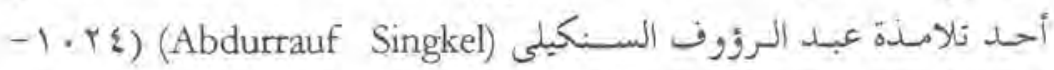

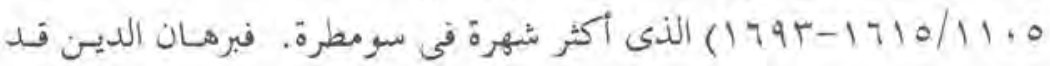

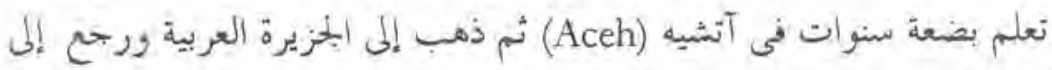

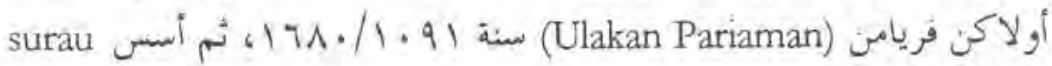

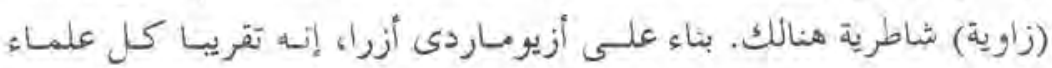

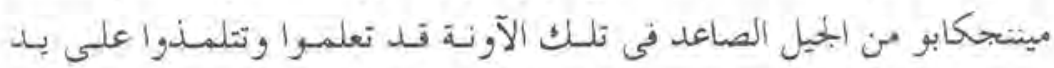

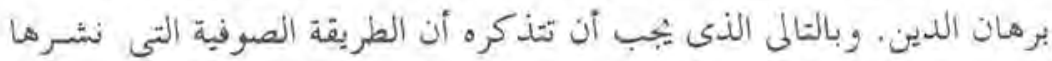

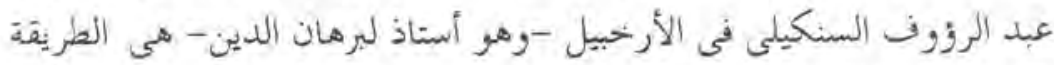

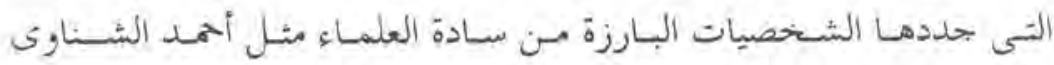

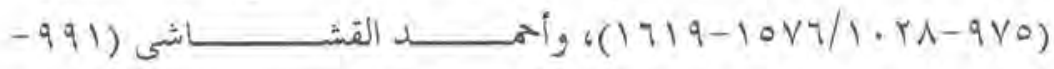

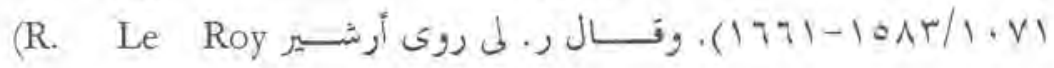
إن الطريقة السئاطرية التى عرفها عبد الرؤوف السنكيلى كطريست : Archer)

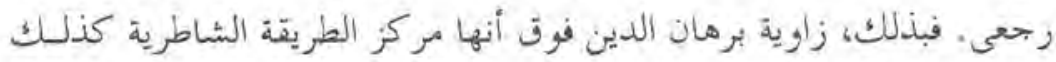

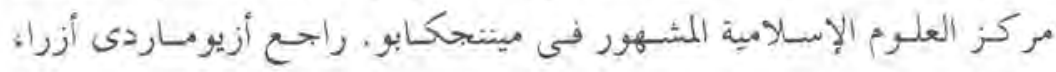
Jaringan ULama Timur Tengah dan Kepulanan Nusantara Abad XT II dan XITII: Melacak Akar-akar Pembarwan Pemikiran Islam di Indonesia

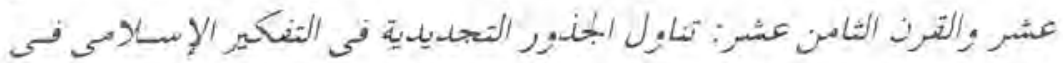

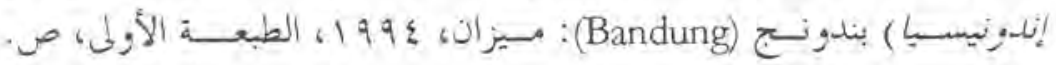

$$
\text { HI. - r. } 9
$$

. . من بين تلاميذ برهان الدين الأكثر شهرة - أو تلميذ تلميذه ومأ بعد ذلكن-

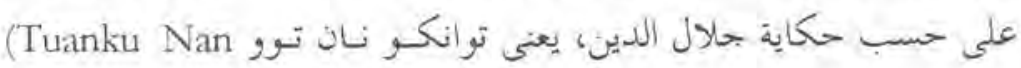


Tuo) (Mansiangan)

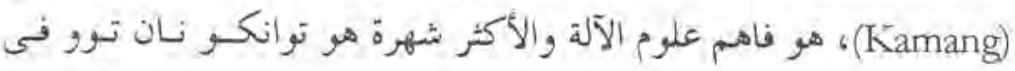

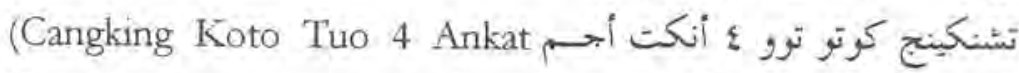
(Agam)

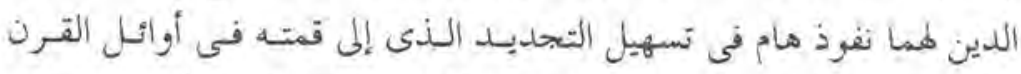

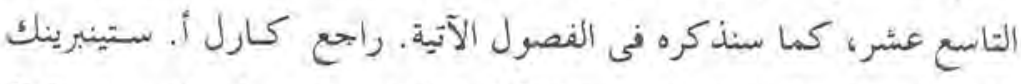
Beberapa Aspek tentang Islam di Indonesia ،(Karel A. Steenbrink) Abad ke-19 بعض صرر عسن الإنسام فسى إندونيسيا فسى التـرن التاسع

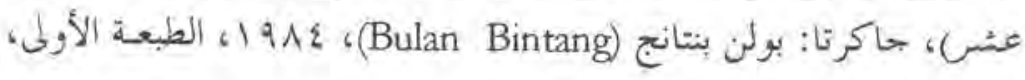
r. ا ا. الذى عرف الطريقة النقشابندية هو جمال الدين (من مينتجكابو) . وهو فيى

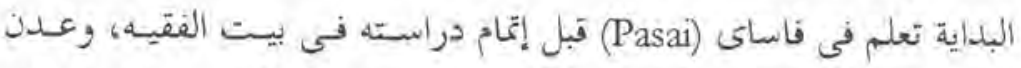

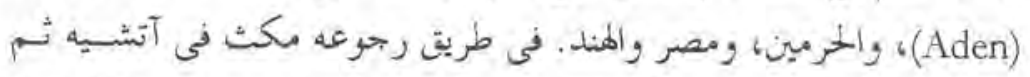

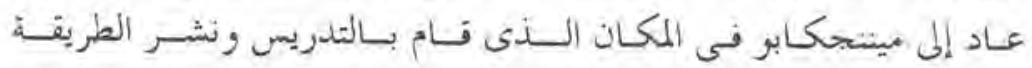

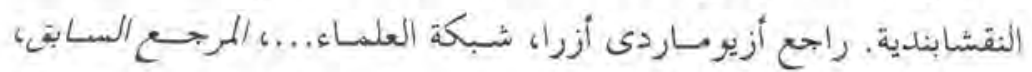

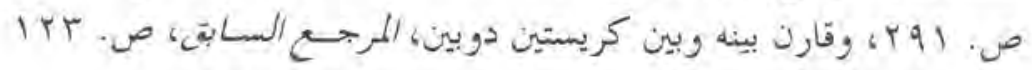

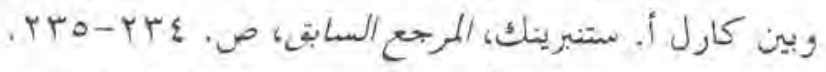

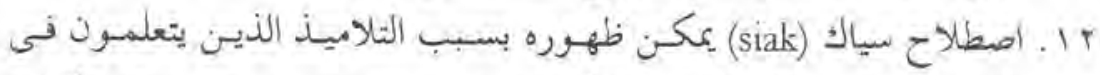

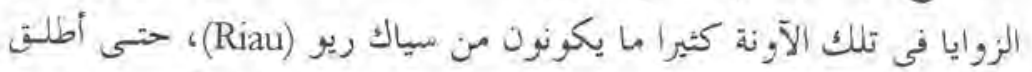

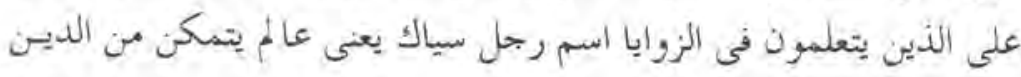
بكامله ويخسن الدعائ. r 1 . . حائرة زاوية باتوهمفر (Batuhampar) واقعة في مسـاحة ثلاثنة هكتارات.

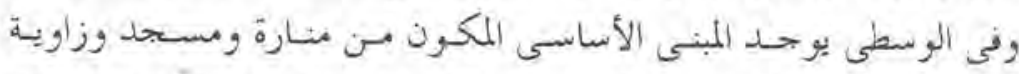

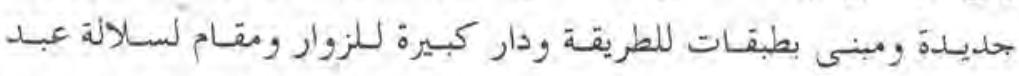

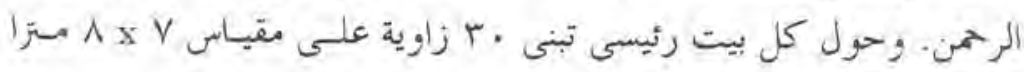


وعلى طبقتين، وتعرف هـذه الدائرة فيــا بعد بـ Kampung Dagang. وهذه الدائرة تزود بسوق صغسيرة، والـذى يـأخذ الانتبـاه أن الزاويسة تطلئق

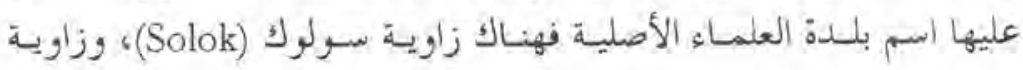

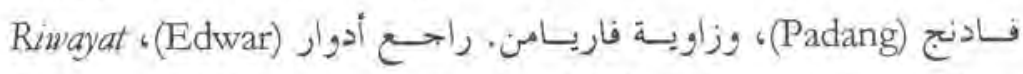
(قصسة حياة Hidup dan Perjuangan 20 Ulama Besar Sumatera Barat

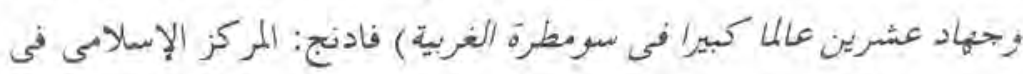

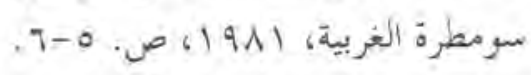

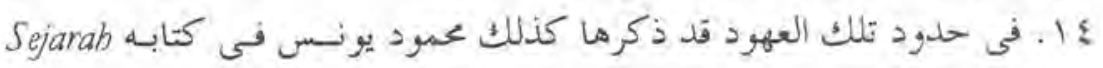
(تساريخ التربية الإنسالامية في إندونيسيا) Pendidikan Islam di Indonesia ولكى في توضيسح في غايسة التحديد وبـالخصوص في علاقته بالتـاريخ الإجتماعى والثقافى المعاصر.

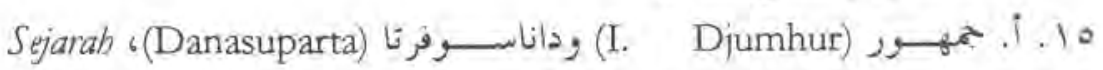
الطبعـة Pendidikan

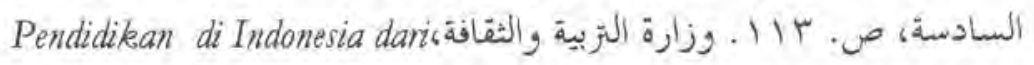

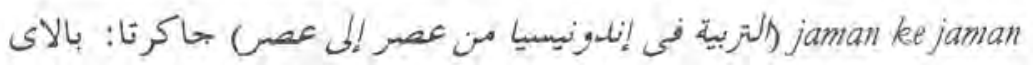
فوستاكا،

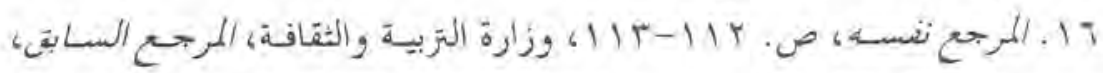

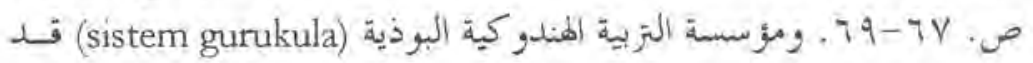

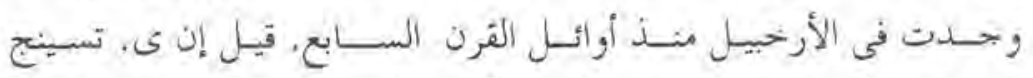

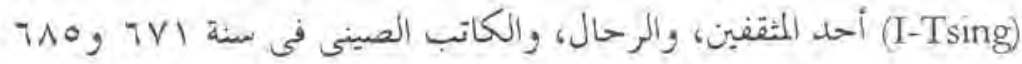

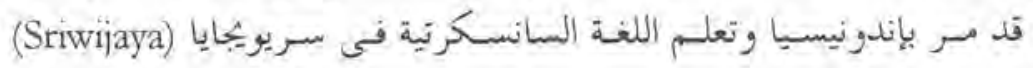

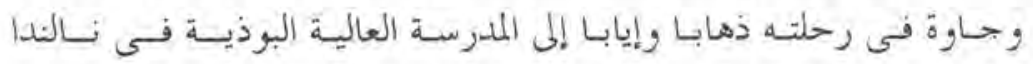

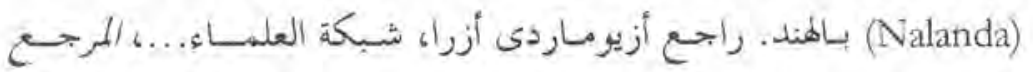

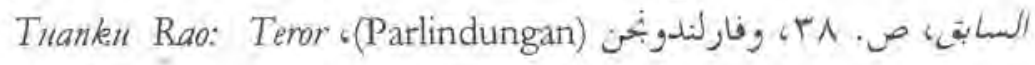
توان Agama Islam Mazhab Hambali di Tanah Batak 1816-1833

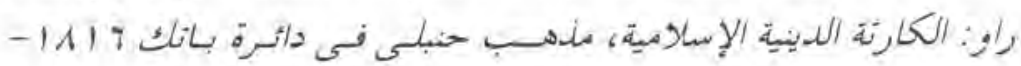




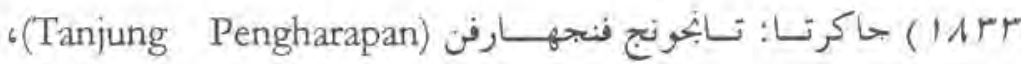

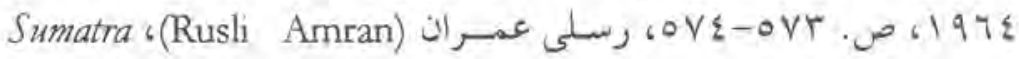
Barat hingga Plakat Panjang

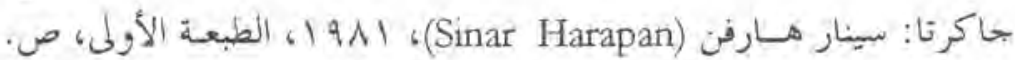
. rq IV (-) Sejarah Pendidikan Islam di Indonesia

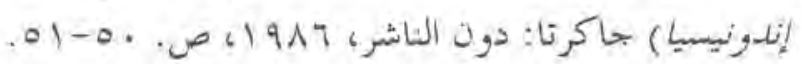

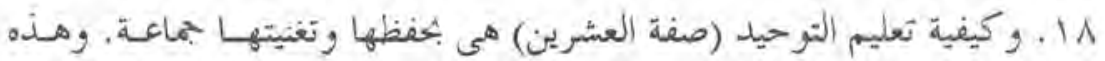

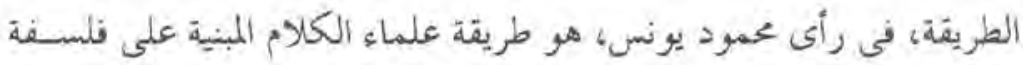

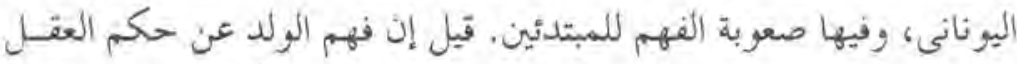

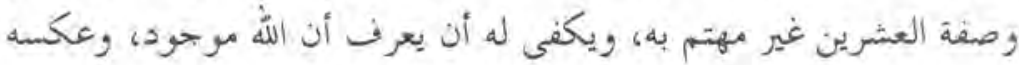

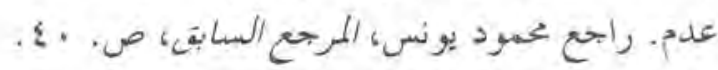
Tradist Pesantren: Studi،(Zamakhsyari Dhofier) 19 tentang Pandangan Hidup Kyai

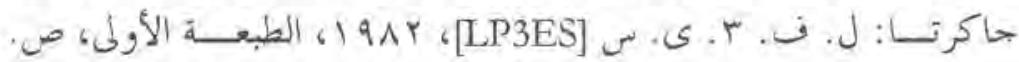
. CHA

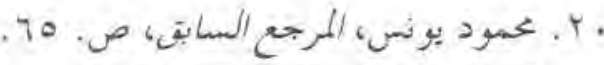

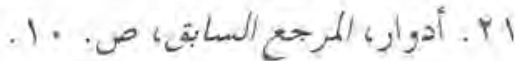

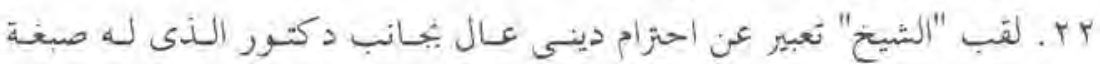

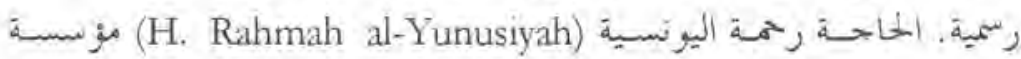

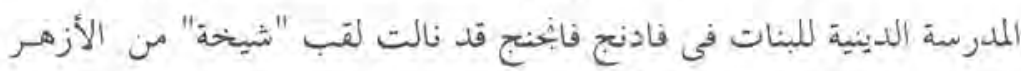

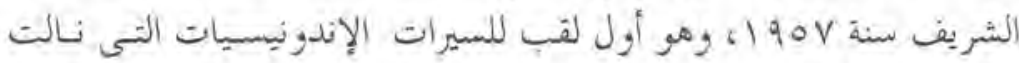
هذا التقدير العلمى الإسلامى.

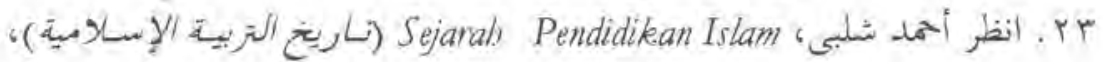

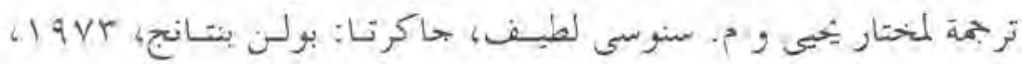




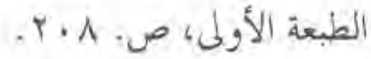

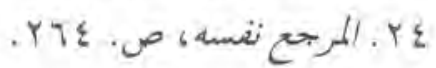

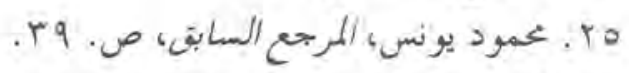

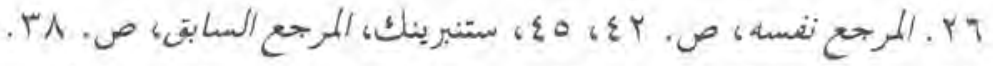

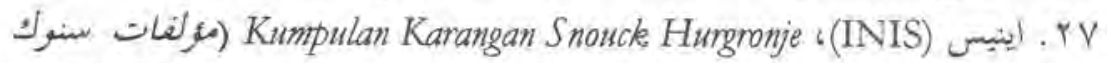
هورغربنية) ترجمة سردرسو سو كارنو (Soedarso Soekarno)، جاكرتسا:

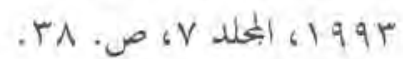

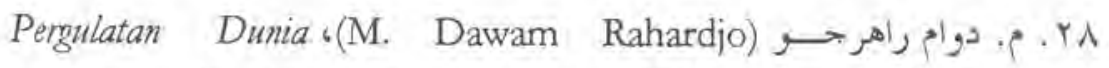
(مeركة عـا لم المعاهد الدينية: البناء: Pesantren: Membangun dari Bawah.

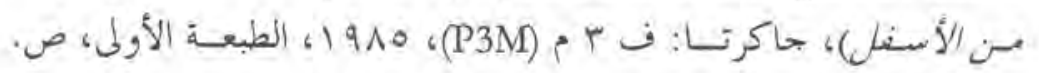

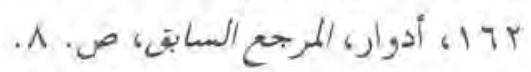

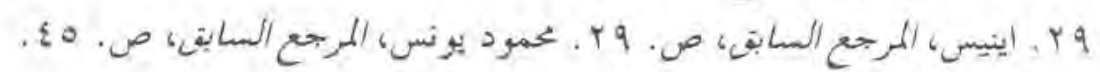

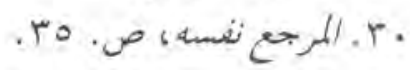

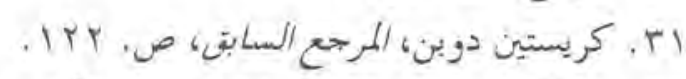

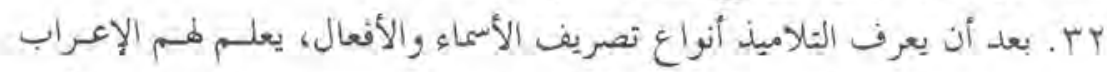

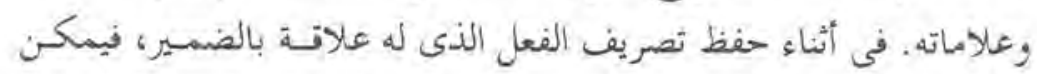

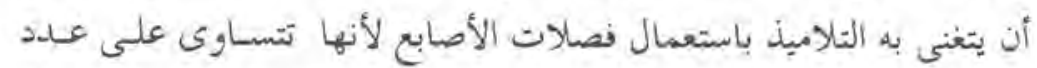

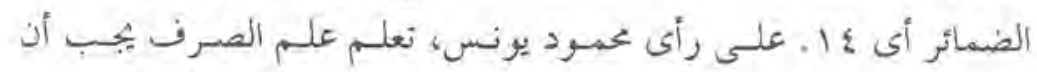

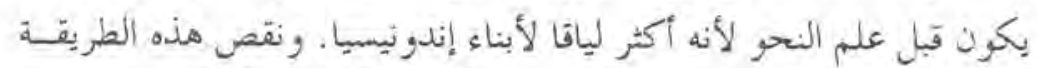

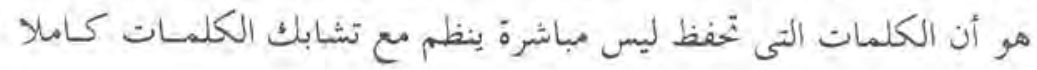

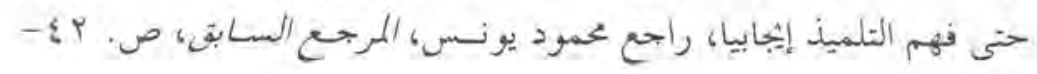
. 5

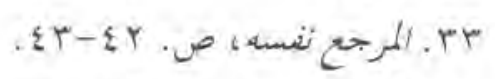

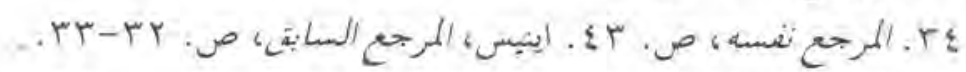

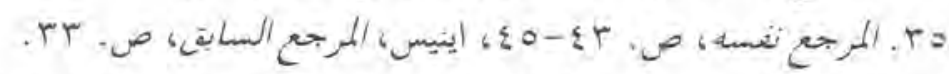

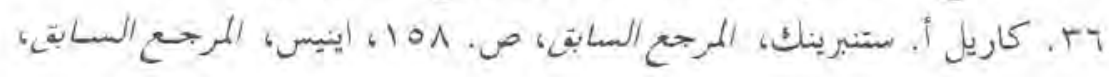


. $+2 \varepsilon$.

VV.r. الظاهر أن بعض الكتب التاريخية توضح الوضع السلبى ذلك في مينتجكابو

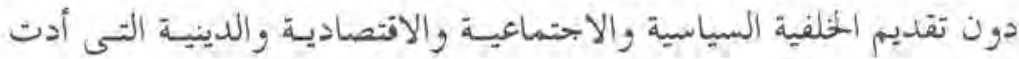

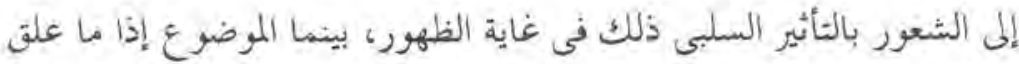

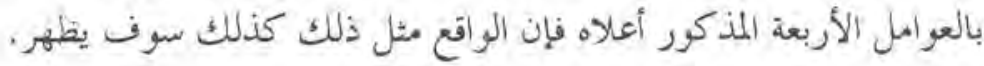

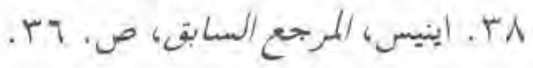

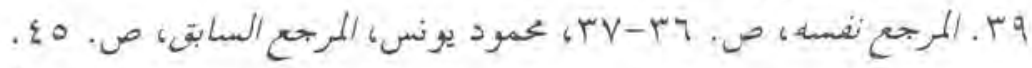

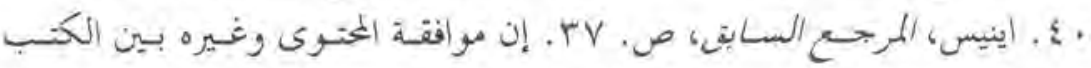

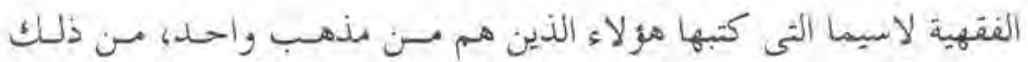

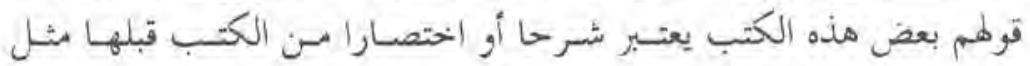

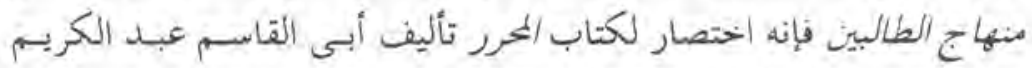

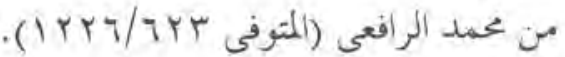

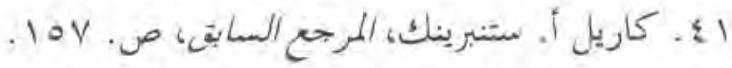

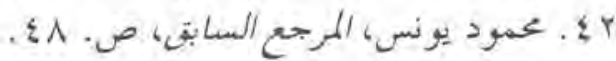

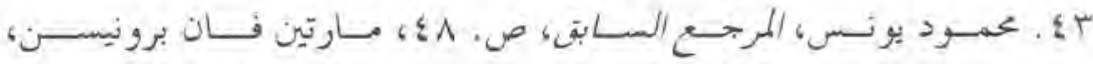
"Pesantren dan Kitab Kuning" V Vlumul Qur'an

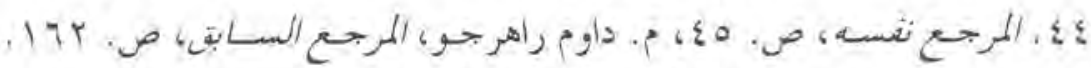

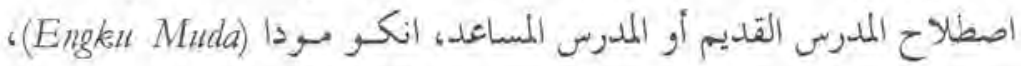

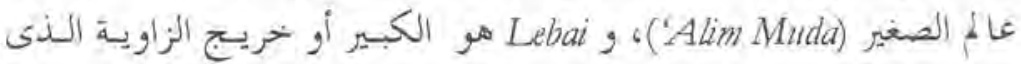

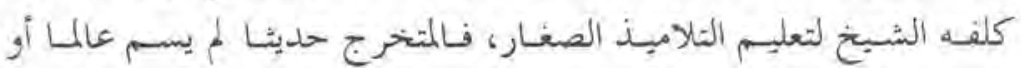

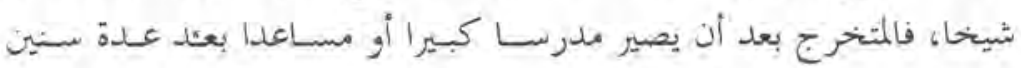

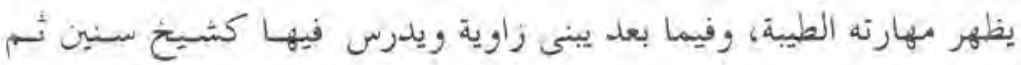

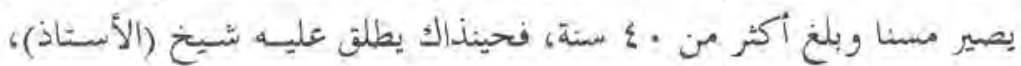

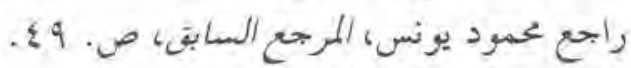

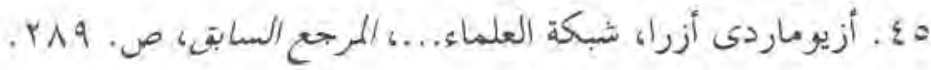




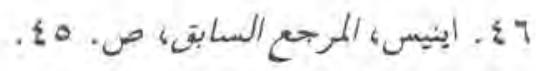

V V . هذه الحالة كما قد ذكرناها فى الفصول السمابقة (انظر إلى الهامش رقــم 9،

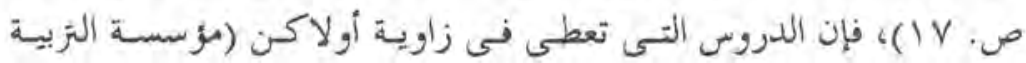

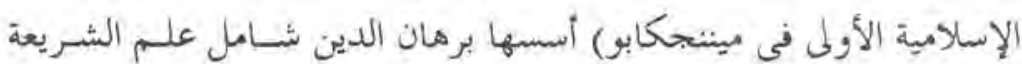

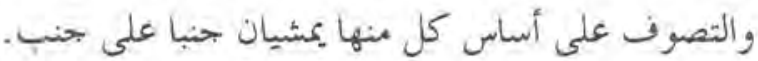

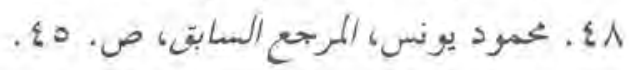

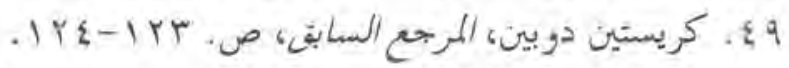

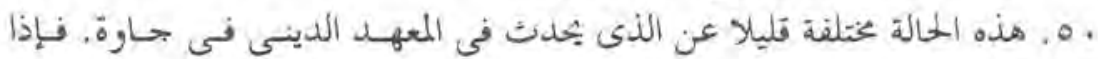

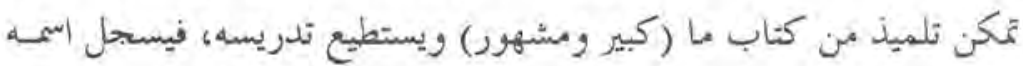

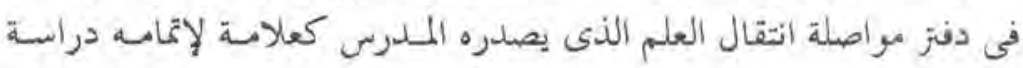

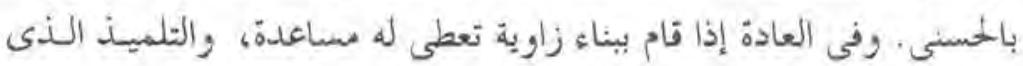

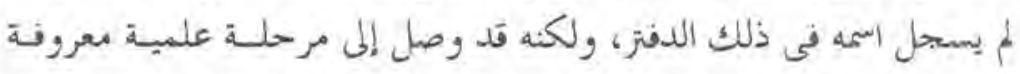

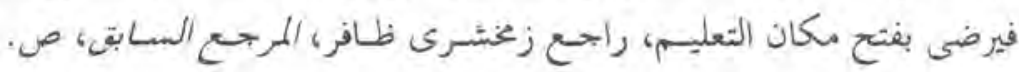
. $T E-r r$

10 . كا ذكريا أن نعليم الطريقة الشاطرية التى قام بترسيعها عبد الـرؤوف بـن

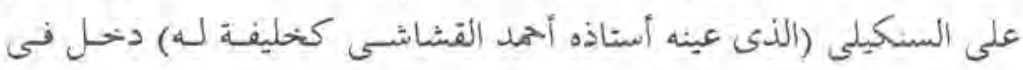

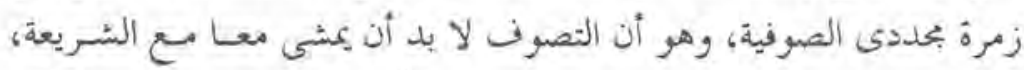

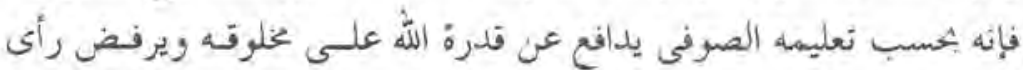

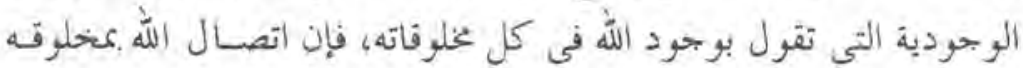

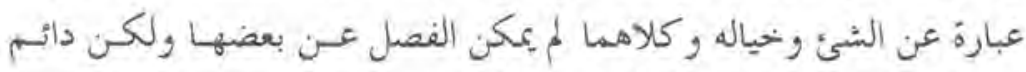

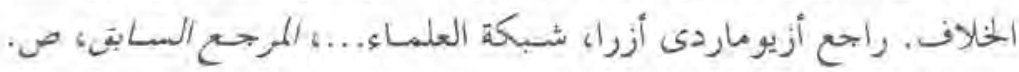
IrT

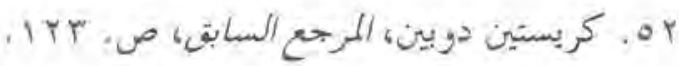

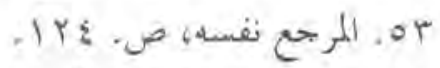

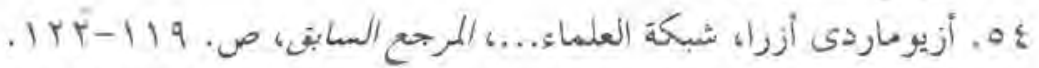

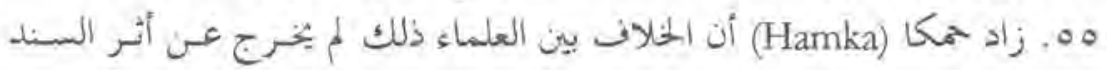


السياسى، ولنلك يستعمل اصطلاح دين تشنجكينج (agama Cangking)

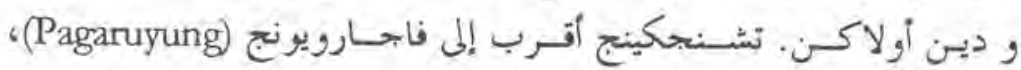

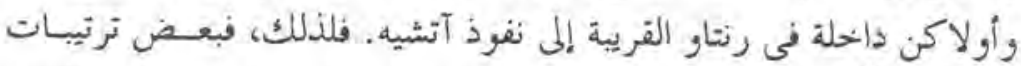

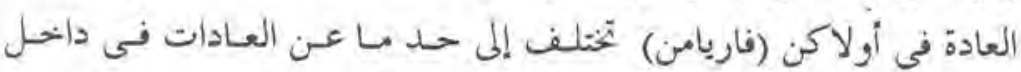

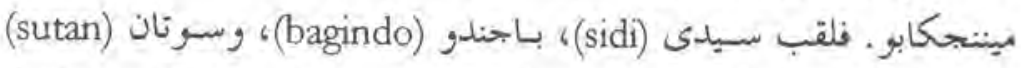

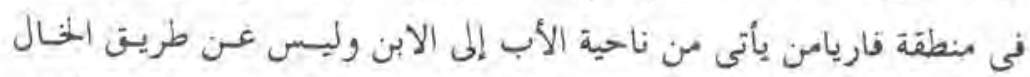

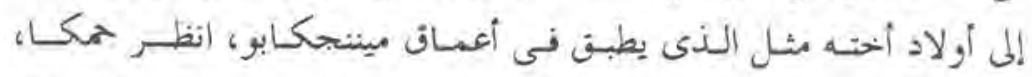
Ayableu: Rinayat Hidup DR H. Abdul Karim Amrullah dan (فصة حيباة اللكتسور الحـاج عبـا Perjuangan Kaum Agama di Sumatra

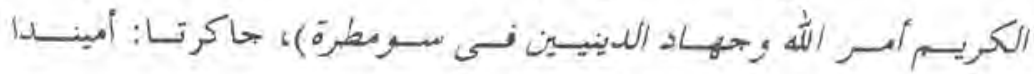
(IT) ، (Umminda)

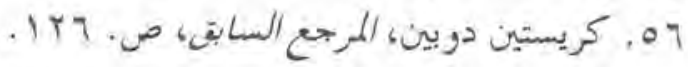

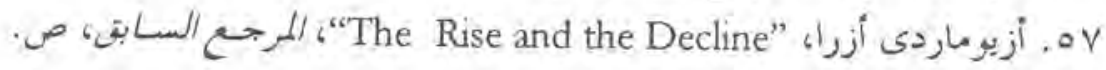
rq

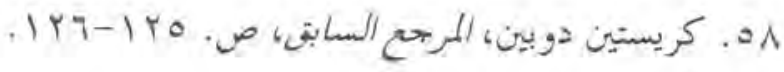

$$
\begin{aligned}
& \text { 09 }
\end{aligned}
$$

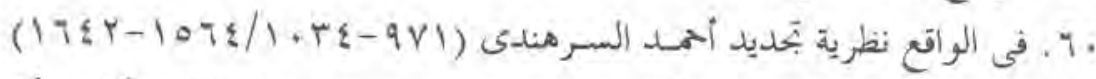

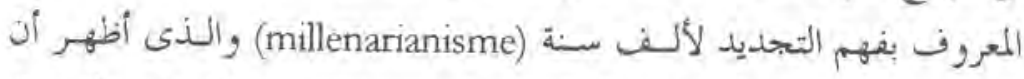
الإسلام يصاب بالتدهور بعـد ألف سنة مس وفـاة الرسيول عليـه الصـلاة

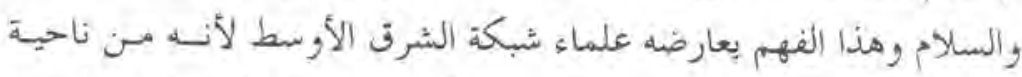

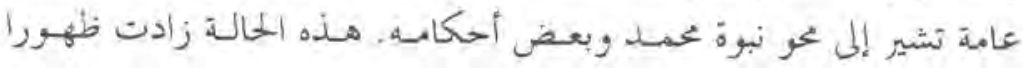

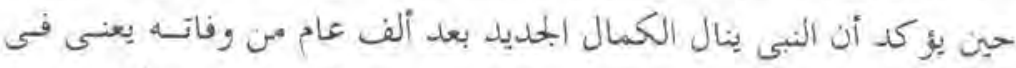

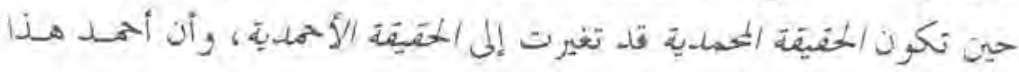

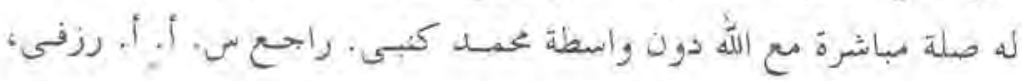

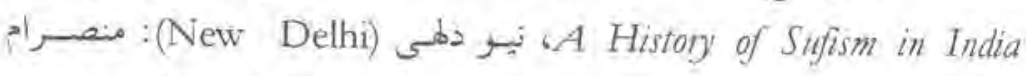

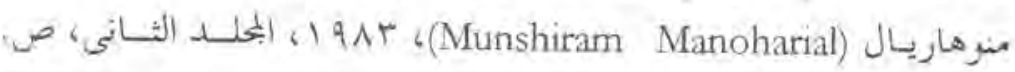




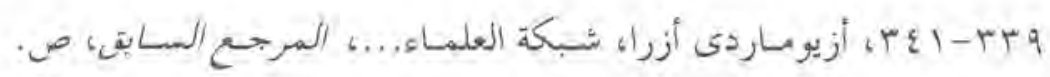
$.1 Y V-1 Y 7$

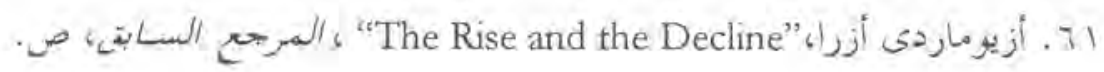
. TV

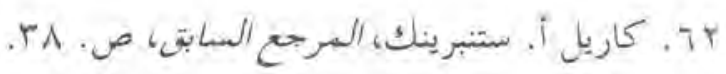

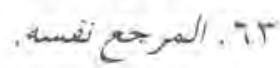

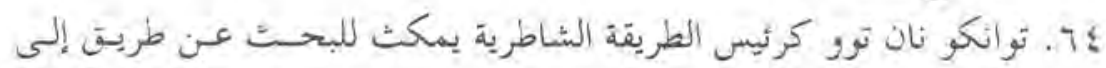

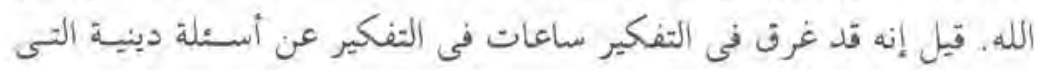

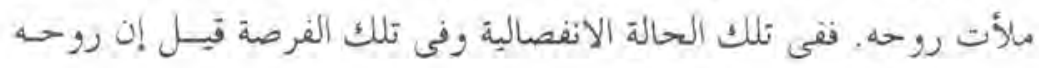

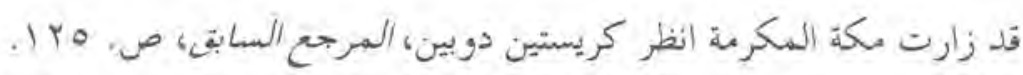

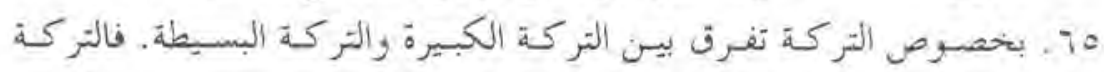

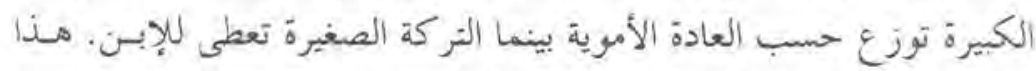

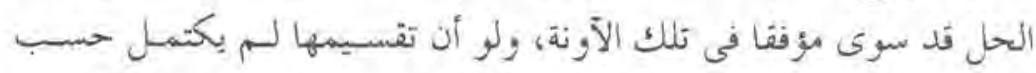

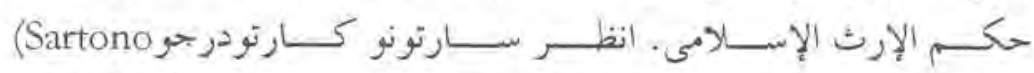
Sejarah Nasional Indonesia Kartodirdjo)

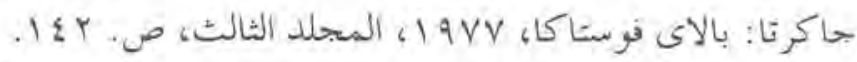

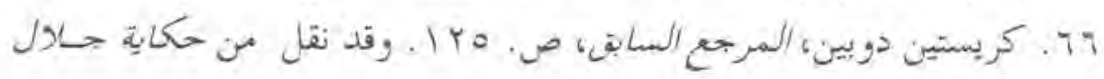

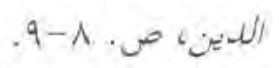

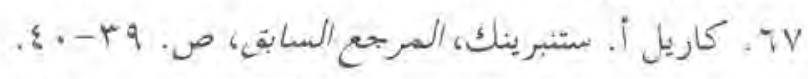

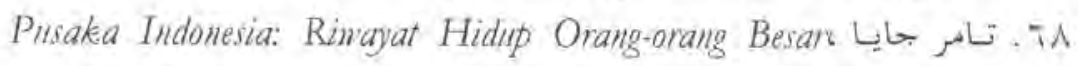
(التركة الإنبونيسية: قصة حياة كبار رجال الوطن) جاكرتسا: Tallah Air

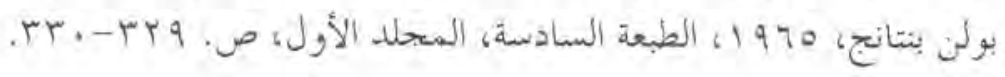

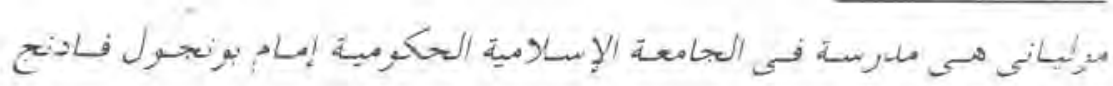
مبرمطرة الغربية. 